\title{
Cor, intelectuais e nação na sociologia de Guerreiro Ramos
}

\author{
Color, intellectuals and nation in Guerreiro Ramos' Sociology \\ Marcos Chor Maio ${ }^{1}$ \\ Fundação Oswaldo Cruz / Casa de Oswaldo Cruz, Programa de Pós-graduação em História das Ciências e da Saúde, \\ Rio de Janeiro- RJ, Brasil
}

\begin{abstract}
Resumo
Este artigo analisa os estudos sociológicos de Guerreiro Ramos sobre as relações raciais no Brasil durante seu engajamento no Teatro Experimental do Negro e por ocasião de suas críticas aos estudos da Unesco, sobretudo nos debates com os sociólogos Luiz de Aguiar Costa Pinto e Roger Bastide, quando já se tornara um intelectual vinculado ao Instituto Brasileiro de Estudos Sociais e Políticos (IBESP), futuro ISEB. A produção sociológica de Guerreiro Ramos não apenas apresenta o ambiente intelectual, os padrões de trabalho científico no domínio da sociologia, mas também revela os impactos dessas investigações na prática das ciências sociais no Brasil. As controvérsias denotam o desenvolvimento da institucionalização das Ciências Sociais marcado por disputas quanto aos rumos que este processo deveria tomar em um país em acelerado processo de mudança social.
\end{abstract}

Palavras-chaves: Pensamento social no Brasil. Racismo. Alberto Guerreiro Ramos. Teatro Experimental do Negro. História das Ciências Sociais no Brasil.

\begin{abstract}
This article analyzes the sociological studies of Guerreiro Ramos on race relations in Brazil during his activism in the Black Experimental Theater and on the occasion of his criticism of the UNESCO studies, especially discussions with sociologists Luiz de Aguiar Costa Pinto and Roger Bastide, when had become an intellectual linked to the Brazilian Institute of Social and Political Studies (IBESP), ISEB in the future. The sociological works of Guerreiro Ramos not only shows the intellectual environment, scientific work standards in the field of Sociology, but also reveals the impact of these investigations on the practice of Social Sciences in Brazil. The controversies revealed the process of the institutionalization of Social Sciences, marked by disputes about the way this process should take in a country undergoing a rapid social change.
\end{abstract}

Keywords: Social thought in Brazil. Racism. Alberto Guerreiro Ramos. Black Experimental Theater. History of Social Sciences in Brazil.

Artigo submetido em 26 de janeiro de 2015 e aceito para publicação em 14 de julho de 2015.

DOI: http://dx.doi.org/10.1590/1679-395152996

1 Doutor em Ciência Política pelo Instituto Universitário de Pesquisas do Estado do Rio de Janeiro (IUPERJ); Pesquisador Titular da Casa de Oswaldo Cruz/FIOCRUZ; Professor do Programa de Pós-graduação em História das Ciências e da Saúde (COC/FIOCRUZ). Endereço: Avenida Brasil, 4036 - sala 400 - CEP 21040-361, Rio de Janeiro - RJ, Brasil. E-mail: maio@fiocruz.br 


\section{Introdução}

A década de 1950 compreende um período de importantes programas de pesquisa no campo das ciências sociais no Brasil. Antropólogos e sociólogos voltaram-se para o exame das possibilidades de desenvolvimento do país e o papel que caberia a eles assumir. A análise das transformações vinha acompanhada pela avaliação das chamadas "resistências às mudanças", a exemplo do Convênio Universidade de Columbia/Estado da Bahia e do projeto do Vale do São Francisco. Estes investimentos acadêmicos e políticos envolveram parcerias internacionais em contexto de avanço da institucionalização das Ciências Sociais e de reconhecimento dos cientistas sociais como agentes da mudança.

Dos projetos em curso nesse período, destaca-se o ciclo de pesquisas sobre as relações raciais no Brasil, sob a chancela da Unesco. A origem do programa de estudos está associada à agenda antirracista formulada pela agência internacional no final dos anos 1940, ainda sob o impacto do genocídio nazista, da persistência do racismo, do processo de descolonização africano e asiático, e dos primeiros passos da Guerra Fria. Em meio ao debate sobre o valor heurístico do conceito de raça sob o patrocínio da Unesco, o Brasil foi concebido como um laboratório que atestaria cientificamente uma sociedade sem raças, como um contraponto positivo, em perspectiva comparada, às experiências do racismo nos EUA e na África do Sul.

Como consequência dessa premissa inicial da Unesco, uma rede transatlântica de cientistas sociais (Charles Wagley, Roger Bastide, Virginia Leone Bicudo, Luiz de Aguiar Costa Pinto, Oracy Nogueira, Aniela Ginsberg, Florestan Fernandes, Thales de Azevedo, René Ribeiro, Edson Carneiro, Marvin Harris, entre outros) desenvolveu pesquisas no Rio de Janeiro, São Paulo, Pernambuco e Bahia, em áreas tradicionais e modernas, gerando um novo, amplo e diversificado quadro interpretativo das relações raciais no Brasil.

Desde o período de gestação do programa de estudos da Unesco, no segundo semestre de 1950, Alberto Guerreiro Ramos, sociólogo do Departamento de Administração do Serviço Público (Dasp) e militante do Teatro Experimental do Negro (TEN), buscou influir no desenho definitivo do projeto, tensionando-o em uma direção abertamente política e de cunho pragmático. No $1^{\circ}$. Congresso do Negro Brasileiro, organizado pelo TEN, Guerreiro Ramos sugeriu à Unesco que patrocinasse um Congresso Internacional de Relações de Raça, a fim de definir uma agenda politicamente orientada, de intervenção social, ao invés de investigações de natureza acadêmica ou estritamente descritivas, que não permitiam uma visão esclarecida sobre a discriminação racial no país. A seu ver, a Unesco devia examinar as atividades de caráter sociológico ou psicossocial realizadas pelo TEN, que constituíam experimentos psicossociais de efeitos práticos imediatos, voltados para a valorização da subjetividade e da estética de negros e mestiços.

No elenco das sugestões feitas pelo sociólogo, destacam-se a difusão de técnicas de dramatização e atividades teatrais como recursos terapêuticos, e a promoção em larga escala de concursos de beleza entre mulheres negras e mulatas (GUERREIRO RAMOS, 1982[1950], p. 237-238). O sociólogo visava - mediante a superação dos ressentimentos e dos recalques suscitados pelo preconceito racial e a alteração das atitudes e mentalidades negativas de brancos e negros referentes à cor - estimular a integração efetiva da população negra à sociedade brasileira. Nesse sentido, Guerreiro também defendeu a implementação de políticas sociais, de educação e formação profissional que contribuíssem para a ascensão social do negro.

A proposta de Guerreiro Ramos destoava da iniciativa da Unesco. A instituição multilateral estabeleceu como meta financiar um conjunto de pesquisas sobre as relações raciais no Brasil que servissem de subsídio para uma ampla campanha educacional contra o racismo. As duas propostas tinham afinidades políticas, mas se diferenciavam quanto aos meios. Guerreiro privilegiou a experiência do ativismo negro e de uma sociologia de cunho eminentemente prático que vinha seguindo desde os primórdios de suas atividades profissionais, quando desenvolveu estudos sobre puericultura, mortalidade infantil, padrão de vida e pauperismo. Ele acreditava que o estudo sociológico e a ação prática deviam ser concomitantes, de tal forma que a formulação das pesquisas exigia uma clara definição de seus objetivos políticos.

A Unesco, por sua vez, elegeu o conhecimento a ser produzido por um conjunto de cientistas sociais tendo em vista subsidiar a ação política. Também houve esforços por parte de cientistas sociais envolvidos no projeto no sentido de evitar que as expectativas da agência internacional em torno da eventual aplicabilidade 
do conhecimento produzido interferissem diretamente ou "contaminassem" a elaboração e a condução das pesquisas locais que, embora motivadas por razões extracientíficas, deviam ocorrer sob determinado grau de autonomia, condição vista como necessária para a objetividade da investigação.

Guerreiro Ramos foi um crítico severo dos estudos elaborados pelos cientistas sociais envolvidos no "projeto Unesco de relações raciais". Mediante as controvérsias em torno do "problema do negro", do "negro como objeto de estudo", Guerreiro Ramos desenvolveu nova leitura sobre o pensamento social brasileiro, inspirado em intelectuais que, desde a segunda metade do século XIX, vinham pensando o tema da incorporação de estratos sociais marginalizados à nação. Nesse período, em parte informado pela experiência do TEN, o sociólogo radicaliza sua perspectiva sobre o afazer sociológico, esboçando uma política para as ciências sociais no Brasil em prol da organização do trabalho de pesquisa em bases coletivas e subordinado a uma agenda política, em cujo interior assumia centralidade a questão do desenvolvimento nacional.

Este artigo analisa a sociologia de Guerreiro Ramos no contexto de sua atuação no Teatro Experimental do Negro e por ocasião de suas críticas aos estudos da Unesco, sobretudo nos debates com os sociólogos Luiz de Aguiar Costa Pinto e Roger Bastide, quando já se tornara um intelectual vinculado ao Instituto Brasileiro de Estudos Sociais e Políticos (IBESP), futuro ISEB. A produção sociológica de Guerreiro Ramos não apenas apresenta o ambiente intelectual, os padrões de trabalho científico no domínio da sociologia, mas também revela os impactos dessas investigações na prática das ciências sociais no Brasil. As controvérsias denotam o caráter tenso da institucionalização das Ciências Sociais marcado por disputas quanto aos rumos que este processo deveria tomar em um país em acelerado processo de mudança social.

Na primeira parte do artigo, discorro sobre as relações entre origem social, formação intelectual e cor na trajetória do sociólogo baiano. Evidencio que sua condição de mulato gerou tensões em seu processo de ascensão social. Na segunda, abordo a militância de Guerreiro no TEN, especialmente sua proposta de formação de uma intelligentsia negra. Na terceira parte, analiso as controvérsias entre Guerreiro Ramos, Costa Pinto e Roger Bastide para finalmente me deter nas relações entre o projeto de uma sociologia brasileira e a questão racial no país na perspectiva do sociólogo baiano.

\section{Origem social, formação intelectual e cor em Guerreiro Ramos}

Em setembro de 1949, no discurso de posse como diretor do Instituto Nacional do Negro, Guerreiro Ramos expôs as razões que o levou a adiar por cinco anos seu ingresso no TEN. Ele desconfiava dos interesses políticos do associativismo negro, movidos pelo ressentimento e pelo isolamento como estratégias de luta contra o preconceito racial (GUERREIRO RAMOS, 1950, p. 35).

Os juízos críticos de Guerreiro guardavam relação com uma série de controvérsias entre intelectuais, políticos e lideranças do associativismo de cor em torno da natureza e da legitimidade do movimento negro enquanto ator político no combate ao racismo no país da ideologia da miscigenação. No centro da contenda, residia a crença de que as agremiações de cor preconizavam a ideologia do "racismo às avessas", uma demasiada ênfase na valorização dos negros, sendo assim acusadas de seguirem o modelo norte-americano, por supostamente terem inventado uma "linha de cor", espécie de artificialismo racial (Maio, 1999a). Guerreiro estava ciente dessa reação conservadora. Ele considerava que a filiação "tardia" no TEN guardava relação com a sua condição de "um homem pegado de mau jeito pela sorte (...) com a vida por organizar" (GUERREIRO RAMOS, 1950, p. 35). Esta sintética definição de seu status requer uma apresentação de sua trajetória social e intelectual. Afinal, qual seria o fardo carregado por Guerreiro Ramos? ${ }^{2}$

Nascido em Santo Amaro da Purificação (BA), Guerreiro Ramos (1915-1982) passou a infância em cidades pobres às margens do rio São Francisco, como Januário, Pirapora, Petrolina e Juazeiro, oriundo de uma modesta família de mulatos. Com a morte do pai, capitão do Exército, migrou para Salvador nos anos 1920.

2 Inspiro-me na frase de Guerreiro Ramos: "É preciso não carregar a pele como um fardo". Ela é a epígrafe do livro Fala Crioulo de Haroldo Costa (1982). 
A mãe tornou-se lavadeira, permitindo que Guerreiro se aproximasse de famílias da elite local (Calmon, Alves e Valadares) e estimulasse seu ingresso no Ginásio da Bahia, prestigiosa instituição do ensino público estadual. $^{3}$

Ainda na juventude, foi da Ação Integralista Brasileira e escreveu crítica literária no Imparcial, órgão que pertencia a simpatizantes da AIB. Militou também no Centro Católico de Cultura, sob a influência de Jacques Maritain, Emmanuel Mounier e das revistas L'Ordre Noveau e Esprit (NASCIMENTO, 1950a, p. 2). A participação em movimentos de cunho político e religioso ampliou o raio de ação de Guerreiro Ramos entre setores da classe média baiana (AZEVEDO, 2006).

No final dos anos 1930, Guerreiro Ramos foi indicado pelo ex-integralista Rômulo de Almeida para o setor cultural do Departamento Estadual de Imprensa e Propaganda (DEIP), órgão criado pelo Estado Novo cuja direção coube a Isaías Alves, ex-integrante da AIB e Secretário de Educação do Estado da Bahia, criador da Faculdade de Filosofia da Bahia e irmão do Interventor no Estado, Landulfo Alves (OLIVEIRA, 1995, p. 27).

Inserido em círculos integralistas, católicos e estadonovistas, Guerreiro Ramos chegou ao final da década de 1930 na condição de um mulato no mundo dos brancos da classe média baiana. Não sem custos, como se pode verificar a partir de sua amizade com Afrânio Coutinho, intelectual e bibliotecário da Faculdade de Medicina da Bahia. Eles criaram a revista $O$ Norte, vinculado ao Centro Católico de Cultura. Os dois mantinham afinidades intelectuais e religiosas, mas romperam as relações de amizade (idem, OLIVEIRA, 1995, p. 28). Mais tarde, Afrânio Coutinho apresentou sua versão do afastamento: "o mulato é um ser (...) carregado de complexos, é um ser complicado, e vive uma vida entre dois mundos, o mundo do preto e o mundo do branco (...). Ele luta contra o branco (...) para subir a escala social, para encontrar o branco (...). De modo que ele luta contra os dois pólos, é um ser dividido entre dois pólos". ${ }^{4}$ Em princípio, Coutinho faz lembrar a análise de Stonesquist (1937) sobre o homem marginal, que vive entre dois mundos, com efeitos psicológicos em suas ações em virtude de uma série de ambivalências. Na verdade, Coutinho deixa transparecer em seu relato visões estereotipadas sobre o mulato como ser pernóstico, complexado, ambíguo. Atribui à cor da pele de Guerreiro a razão do conflito entre eles.

Guerreiro Ramos migrou para o Rio de Janeiro no final de 1939 com uma bolsa de estudos do Governo do Estado da Bahia. Nos primórdios de sua estada na cidade, manteve laços intelectuais e políticos com grupos católicos e de ex-integralistas. Ele colaborou com artigos sobre cultura na revista Cadernos da Hora Presente (GUERREIRO RAMOS, 1939), publicação que reuniu antigos integralistas, e Cultura Política (Guerreiro Ramos, 1941), revista patrocinada pelo Estado Novo. Nos dois primeiros anos do curso de Ciências Sociais na Faculdade Nacional de Filosofia (FNFi), continuou interessado em literatura, poesia, filosofia e religião, guardando certa distância das ciências sociais. ${ }^{5}$ Em 1942, no terceiro e último ano da graduação, Guerreiro Ramos voltou-se para a produção nas áreas da sociologia e da antropologia, incluindo os estudos afro-brasileiros de Arthur Ramos (O Negro Brasileiro, 1934; Folklore Negro no Brasil, 1937) e o livro de Karl Mannheim, centrado no tema da planificação (Libertad y Planificacion, 1942). Ademais, teve contato com a Escola Sociológica de Chicago (An Outline of the Principles of Sociology, Robert Park e Samuel Smith, 1939).

Contribuiu para a aproximação de Guerreiro Ramos da sociologia americana o ciclo de conferências ministrado pelo sociólogo Donald Pierson, da Escola Livre de Sociologia e Política (ELSP), a convite do DASP, no segundo semestre de 1942 sobre métodos e técnicas de pesquisa (PIERSON, 1945). Pierson

\footnotetext{
${ }^{3}$ Parte das informações biográficas foram extraídas de Guerreiro Ramos (1995); Nascimento (1950); Diário Oficial, 16/01/1897, p. 16; 03/08/1910, p. 6062; A Notícia, 31/10/1914, p. 5; carta de Clélia Guerreiro Ramos ao autor, 23/08/1996.

${ }^{4}$ Entrevista de Afrânio Coutinho ao autor, 28/06/1995.

${ }^{5}$ Obras consultadas por Guerreiro Ramos na Biblioteca da FNFi, de autores como Platão, Nietzsche, Goethe, Proust, Cocteau, Mallarmé e Brémond. Estes autores, nas leituras de Guerreiro Ramos, passam a dividir espaço com trabalhos de cientistas sociais como Arthur Ramos, Karl Mannheim, Maurice Halbwachs, Pitirim Sorokin, Wilhelm Dilthey, Robert Park, etc. Catálogo TopográficoBiblioteca. Arquivo FNFi/PROEDES/UFRJ.
} 
propugnava uma "sociologia científica" que rompesse com o "ensaísmo" da tradição do pensamento social no Brasil (OLIVEIRA, 1995; MAIO e LOPES, 2012, p. 301-306).

Após a tentativa frustrada de se tornar assistente da disciplina Ciência Política, ministrada pelo francês André Gros, em função de seu passado integralista (GUERREIRO RAMOS, 1995, p. 140) ${ }^{6}$, Guerreiro foi indicado pelo diretor da FNFi, San Tiago Dantas, ex-militante da AIB, para professor da cadeira de Problemas Econômicos e Sociais do Brasil, do Departamento Nacional da Criança (DNC) (GUERREIRO RAMOS, 1944, p. 3). Em sua atuação no DNC, é evidente a influência da sociologia de Chicago, principalmente os estudos sobre desajustamentos sociais (delinquência juvenil), problemas urbanos e propostas de ações terapêuticas para o comportamento de "menores infratores" em clínicas sociológicas. Tais temas traduzem seu interesse pelo caráter aplicado das ciências sociais (LOPES, 2012)

No final de 1943, o sociólogo entrou para o quadro técnico do Departamento de Administração do Serviço Público (DASP), onde permaneceu por seis anos dedicando-se à reflexão sociológica sobre a puericultura, mortalidade infantil, medicina popular e administração (MAIO e LOPES, 2012). Em sua dupla militância de burocrata e intelectual, Guerreiro desenvolveu seu lado acadêmico, conquistando espaços ao funcionário (OLIVEIRA, 1995). Além das atividades no setor de métodos de trabalho, planejamento e treinamento de pessoal do DASP, ele integrou a equipe editorial da Revista do Serviço Público, espaço em que deu vazão, em grande parte, à sua produção acadêmica até o final dos anos 1940. Constam da publicação artigos sobre Weber, Mannheim, W. I. Thomas, além de resultados de pesquisa e reflexões mais gerais acerca das ciências sociais (SOARES, 1995, p. 35). Em 1949, a pedido do Conselho de Colonização e Imigração, Guerreiro elaborou em coautoria com Ewaldo Garcia o livro Notícias sobre as pesquisas e os estudos sociológicos no Brasil que versa sobre a imigração com base na literatura sociológica e antropológica existente no Brasil entre 1940 e 1949 (GUERREIRO RAMOS e GARCIA, 1949). Este seria o início de uma série de investigações, ampliada nos anos 1950, sobre a intelectualidade brasileira, seu papel social e político, e sua produção.

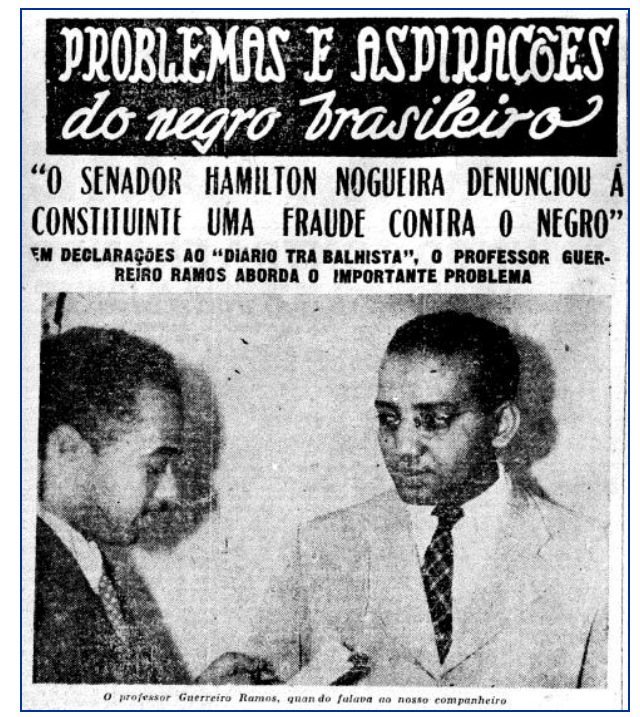

Fonte: Diário Trabalhista, 24.03.1946, p. 6

Abdias Nascimento em entrevista ao professor Guerreiro Ramos, sociólogo do Departamento Nacional da Criança, no momento em que atos racistas eram denunciados por parlamentares em meio aos debates da Constituinte de 1946.

Nesse intervalo, Guerreiro Ramos casou-se com Clélia Calazans Rodrigues de Paula, bibliotecária do DASP, filha do advogado, professor, jornalista, funcionário da mesma instituição, Raul de Paula (1897-1945), um dos líderes da Sociedade dos Amigos de Alberto Torres, grupo de pressão nacionalista que exerceu significativa influência na política imigratória restritiva do primeiro governo Vargas mediante a Lei de Cotas

\footnotetext{
${ }^{6}$ No livro Quinta Coluna e Integralismo (Rio de Janeiro, Departamento Editorial da União Nacional dos Estudantes, 1943 [1942], p. 20), Guerreiro Ramos foi denunciado pela UNE por pertencer aos quadros integralistas. 
de 1934 (LESSER, 1995). Seguindo a tradicional estratégia de ascensão social, Guerreiro Ramos casou-se com uma mulher branca, embora não tenha sido bem aceito pela família em função de sua cor. O matrimônio só se realizou após o falecimento de Raul de Paula. ${ }^{7}$

Com a "marca" da cor, Guerreiro ingressou no Teatro Experimental do Negro (TEN) em 1949. Esta iniciativa não estava destituída de tensões. Na pesquisa sobre as elites de cor em Salvador, patrocinada pela Unesco, o antropólogo Thales de Azevedo fez a seguinte descrição do depoimento prestado por Zilda Guerreiro Ramos, irmã de Guerreiro Ramos, sobre a questão do preconceito de cor na Bahia:

"Profa. Zilda Guerreiro Ramos, mulata clara, cerca de 38 anos, funcionária do D.S.P. É irmã de um dos líderes do movimento pró-negros do Rio (Teatro Experimental do Negro). Disse que a sua família desaprova a atividade do irmão e que este não faz parte propriamente do grupo do T.E.N.: é apenas professor, dá cursos, estuda o problema. (...) Mostra-se perturbada com o assunto e muda de conversa." (AZEVEDO, Ascensão Social das Pessoas de Cor, 1951, p. 63).

$\mathrm{Na}$ entrevista, o tema da cor é fonte de tensão e de ameaça ao status social de Guerreiro, aos olhos de Zilda Ramos. Ela recusa identificar o intelectual com o ativista político, principalmente em se tratando de uma dimensão incômoda como o do racismo. ${ }^{8}$

A sociologia engajada de Guerreiro presente em seus estudos no DNC e no DASP vai adquirir maior visibilidade com sua atuação no Teatro Experimental do Negro, quando se verifica uma crescente crítica de Guerreiro às ciências sociais acadêmicas e, mais especificamente, à abordagem antropológica do negro brasileiro, pensado exclusivamente como objeto de estudo, e não a partir do imperativo da transformação de suas condições de vida. Guerreiro Ramos passa a destacar a necessidade de criação de uma elite negra, de uma intelligentsia que tivesse por missão, ao lado de intelectuais brancos, a formulação de uma política de enfrentamento do racismo.

\section{Guerreiro Ramos e o engajamento no Teatro Experimental do Negro}

Nos primórdios do envolvimento com o TEN, em 1949, Guerreiro Ramos assume três desafios: 1) um projeto de valorização da subjetividade de negros e mulatos, tendo em vista a superação dos recalques provocados pela escravidão e pela exclusão do processo de modernização capitalista, por meio do teatro, do psicodrama, do sociodrama; 2) a formação de uma intelligentsia negra que, ao lado das elites brancas, superasse o descompasso entre a condição formal de cidadão livre adquirida pelo negro após a Abolição e sua adversa situação econômica, e sociocultural, ainda presente nos anos 1940;3) um conjunto de iniciativas de profissionalização de mulatos e negros. ${ }^{9}$

Em meio ao processo de definição de uma agenda para o TEN, Guerreiro Ramos participou da Conferência Nacional do Negro, na qual foi eleito para o comitê organizador do $1^{\circ}$ Congresso do Negro Brasileiro, ao lado de Abdias Nascimento e Édison Carneiro, realizado no ano seguinte. Tornou-se diretor do Instituto Nacional do Negro (INN) e responsável pela realização de cursos nas áreas de educação, cultura e formação profissional, além de promover atividades cênicas e dinâmicas de grupo de caráter psicoterapêutico (GUERREIRO RAMOS, 1949, p. 6). Ele coordenou um seminário de Grupoterapia para os alunos do TEN,

\footnotetext{
7 Entrevista concedida por Sergio Góes de Paula, cunhado de Guerreiro Ramos, ao autor em 01/08/2012.
}

${ }^{8}$ Em entrevista à Alzira Alves de Abreu e Lucia Lippi Oliveira, realizada no dia 09.06.1981, Guerreiro Ramos declara que "eu me meti no negócio do teatro [TEN] e me prejudiquei, inclusive politicamente, porque eu era um sujeito bem colocado, e as pessoas passaram a dizer que eu me misturei com negro" (OLIVEIRA, 1995, p. 175).

9 Para uma análise do pensamento sociológico de Guerreiro Ramos sobre o negro antes de seu ingresso no TEN, ver: Maio (2015) e Muryatan (2004). 
no intuito de formar pessoal habilitado para "atuar nos morros, terreiros e nas associações de gente de cor" (QUILOMBO, 1949, nº 3, p. 11).

Para o sociólogo, a Grupoterapia oferecia, por meio do teatro, a oportunidade para o negro enfrentar seus temores e ressentimentos, expurgando de sua personalidade os estereótipos raciais e as visões autodepreciativas incorporadas desde a infância. Tratava-se da transposição para o palco, de situações de preconceito e conflito concretas, tais como vivenciadas pelo indivíduo ${ }^{10}$. O depoimento de Ruth de Souza, atriz do TEN desde 1945 e que atuara em diversas peças patrocinadas pela organização, permite compreender a proposta psicossocial levada a cabo por Guerreiro Ramos. A experiência de infância da atriz, que viera de uma cidade do interior para o Rio de Janeiro, foi objeto de dramatização no INN, conforme seu relato:

\begin{abstract}
"Minha mãe era do interior. Ela era a Dona Alaíde, dona de um pedaço de terra, uma senhora respeitada (...). E quando nós viemos para o Rio, ela tornou-se lavadeira. Nós éramos a filha da lavadeira, Alaíde a lavadeira, eu me lembro disso. (...) Depois eu comecei a chorar [durante a experiência grupoterápica sob a orientação de Guerreiro Ramos] porque foi quando eu descobri que eu era pobre. Quando eu cheguei no Rio de Janeiro, tornei-me negra, eu não sabia que eu era negra. Sabe, quando criança não presta atenção? E eu lembro disso, que a descoberta de ser negra foi aqui no Rio de Janeiro, a descoberta das diferenças de classes, que eu não entendia. Fui crescendo e não entendendo muito bem porque é que (...) você me trata diferente se eu sou gente igual a você?"
\end{abstract}

A encenação de uma situação em que fora alvo de preconceito, como a "filha da lavadeira" na casa dos patrões da mãe, permitiu à Ruth de Souza uma nova compreensão sobre as causas do episódio, associadas à condição de menina negra e pobre, e à perda de status social da família no contexto urbano. Além de servir de base para a compreensão das relações sociais que marcavam a vida de negros e mulatos, a dramatização produziria um efeito psicológico libertador, restituindo-lhes a autoestima e a confiança nas próprias capacidades criadoras (GUERREIRO RAMOS, 1950c, p. 6; 1950d, p. 9) ${ }^{11}$.

Afora o Seminário de Grupoterapia, o INN desenvolvia atividades educacionais e profissionais. Em carta a Florestan Fernandes, de janeiro de 1950, Guerreiro compartilha com o sociólogo da ideia de "instalar em Caxias, a Meca dos Negros do Estado do Rio de Janeiro, uma Instituição de Orientação Profissional. Por enquanto vai começar com uma escola primária. Mas penso em fazer oficinas de alfaiataria, tipografia, marcenaria, eletricidade e uma escola de domésticas". ${ }^{12}$

No plano político, Guerreiro Ramos analisa o papel da "elite negra" que estava sendo forjada pelo TEN. Para isso, aborda o lugar do negro na sociedade ocidental. A incorporação dos padrões culturais ocidentais pelos negros havia produzido, principalmente entre aqueles com baixo nível de instrução, comportamentos ambivalentes, que oscilavam entre a identificação com as "sobrevivências das culturas negras" e os valores próprios à sociedade moderna ocidental. Esses juízos ambivalentes seriam superados mediante o reconhecimento da contribuição dos negros à civilização ocidental. Nesse sentido, cabia à "elite negra" explorar todo o potencial da "subjetividade negra", da negritude, do seu papel construtivo e revitalizador diante das instituições culturais do Ocidente, marcadas por um processo de burocratização, de engessamento (GUERREIRO RAMOS, 1950, p. 41-43).

\footnotetext{
10 As relações, permeadas de tensão, entre patrões e empregadas domésticas foram um dos temas de encenação no INN (GUERREIRO RAMOS, 1995, p. 173). Em carta a Florestan Fernandes, Guerreiro informa que iniciaria, possivelmente em novembro de 1950, a dramatização do conteúdo dos sonhos de indivíduos negros. Carta de Guerreiro Ramos a Florestan Fernandes, s./d., Fundo Florestan Fernandes, 02.09.0591. Neste caso, chamara-lhe a atenção o trabalho de Roger Bastide apresentado no I Congresso do Negro Brasileiro, cuja análise dos sonhos de indivíduos negros revelava a identificação destes com os padrões estéticos do branco (GUERREIRO RAMOS, 1950b, p. 1 e 3).

${ }^{11}$ Entrevista de Ruth de Souza concedida ao autor em 30/10/1996.

${ }^{12}$ Carta de Guerreiro Ramos a Florestan Fernandes, 4/1/1950, p. 2, Fundo Florestan Fernandes, 02/09/105950.
} 
Com o objetivo de incorporar os negros à modernidade, o TEN devia "adestrar os homens de cor nos estilos de comportamento da classe média e superior" (NASCIMENTO, 1949, p. 11). Guerreiro Ramos foi o principal responsável pelos contornos ideológicos e políticos da ação do TEN. Embora crítico contundente dos estudos antropológicos sobre o negro, que estariam voltados para a tradição, Guerreiro buscou interpretar, assim como Abdias do Nascimento, o universo psicológico do negro a partir de categorias de análise da antropologia (Tylor, Frazer) e da sociologia (Lévi-Bruhl) interessadas no denominado pensamento primitivo, que se encontram nos escritos do antropólogo Arthur Ramos, especialmente no livro O Negro Brasileiro (1934). Inspirado no médico-antropólogo, Guerreiro Ramos concebia a necessidade de se criar instrumentos racionais para sobrepujar as práticas tradicionais radicadas na estrutura dos hábitos e cristalizadas em atitudes. O processo de "disciplinarização" contribuiria para frear, entre outras atitudes, a adesão dos negros a ideologias de esquerda, marxistas, que se alimentavam do ressentimento e buscavam capitalizar politicamente a situação de restrição de direitos que a população negra sofria nos regimes democrático-liberais (GUERREIRO RAMOS, 1950, p. 43). É evidente o contexto da Guerra Fria e o alerta de Guerreiro quanto às adversidades que os negros viviam nos países capitalistas. O sociólogo elogia o Presidente Harry Truman pelos avanços no terreno dos direitos civis. Guerreiro estava distante de qualquer solução de corte marxista e julgava que o papel do TEN era o de "transformar a luta de classes num processo de cooperação", de forjar uma intelligentsia, "uma elite (...) uma espiritualidade e uma missão" (GUERREIRO RAMOS, 1950e, p. 50).

Guerreiro utiliza o conceito de intelligentsia, de corte mannheimiano, em detrimento de qualquer solução do tipo "partido de negros", na medida em que "o homem de cor, entendido como homem-massa, não estaria habilitado às funções de mando, as quais, como é sabido, supõem uma longa aprendizagem". Caberia à intelligentsia negra a elevação social e sem conflitos da "massa negra". (GUERREIRO RAMOS, 1950, p. $38)$.

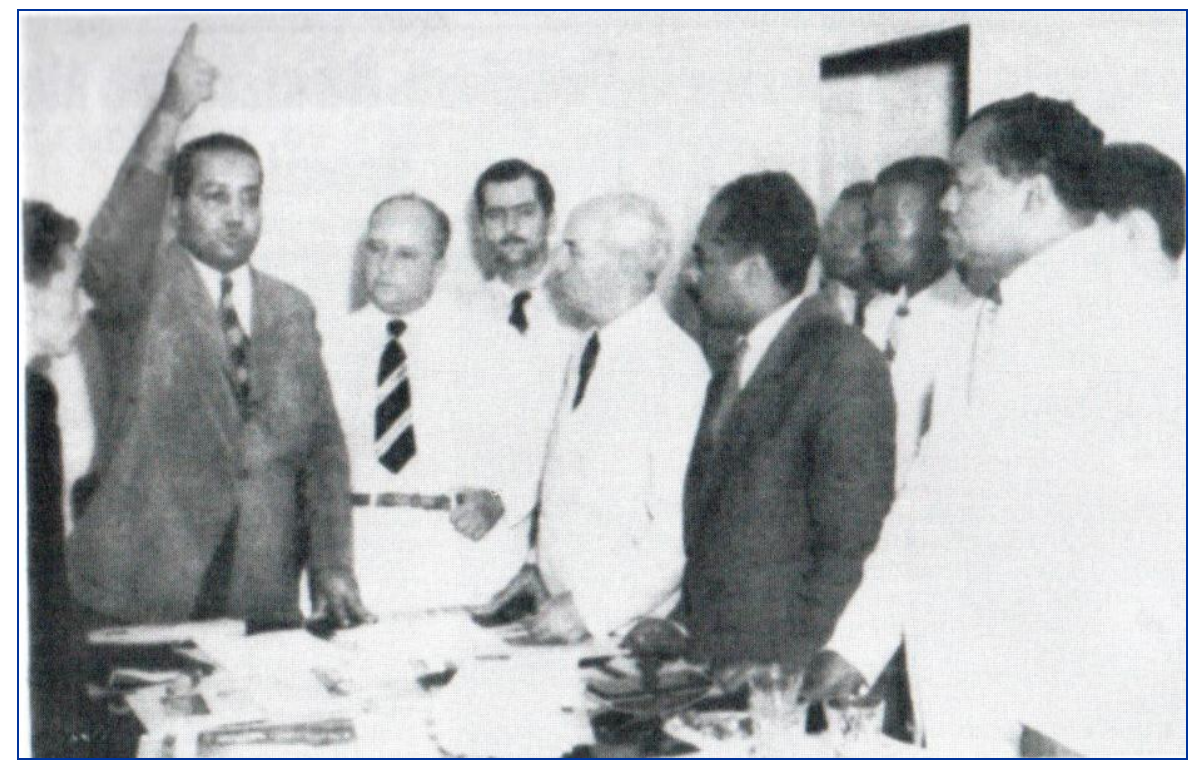

Fonte: Quilombo, nos. 7-8, março e abril de 1950, p. 12.

Guerreiro Ramos em discurso no lançamento da candidatura de Abdias Nascimento a vereador pelo PSD do Distrito Federal nas eleições de outubro de 1950.

Até a década de 1950, o pensamento de Guerreiro Ramos se caracteriza pelas críticas aos estudos afrobrasileiros, de caráter histórico, folclórico ou antropológico. Essas análises, que remontam a década de 1930, envolveram cientistas sociais, intelectuais negros e militantes comunistas (MAIO, 2015, p. 82-84). Todavia, a produção intelectual do TEN do final dos anos 1940 foi mais sistemática no sentido de propor uma mudança de caráter sociológico na abordagem dos estudos tradicionais sobre as relações raciais. Este novo conhecimento informaria a atuação da intelligentsia que, por sua vez, levaria a uma perspectiva dotada de um sentido amplo e prático. Esta visão fica evidente numa entrevista do sociólogo ao jornal Última Hora, em 
junho de 1956, quando faz uma análise de sua atuação no Teatro Experimental do Negro, ressaltando a importância da prática e sua influência decisiva sobre a reflexão teórica. Nas palavras de Guerreiro:

"Na minha vida profissional, aliás, em certo sentido, a prática precedeu a teoria. A nova teoria sobre relações de raça no Brasil, que consegui fazer vitoriosa em nosso meio, representa a indução de uma 'práxis'. O Teatro Experimental do Negro me possibilitou a 'práxis' do 'problema' e depois dele cheguei à teoria. $\mathrm{O}$ mesmo aconteceu com os meus estudos sobre mortalidade infantil e sobre problemas administrativos, econômicos e políticos do país. Quem não age, quem não participa do processo societário não compreende a sociedade." (GUERREIRO RAMOS, 1957, p. 210)

Nos anos 1950, ele amplia essas reflexões na interface entre sociologia, desenvolvimento, papel dos intelectuais e construção da nação.

\section{O Processo da Sociologia no Brasil e os estudos sobre o negro}

O tema do desenvolvimento como conquista da autarquia econômica e da consolidação de uma fisionomia sociopolítica própria para o Brasil, com base em um processo de industrialização capitaneado pelo Estado, constituiu tema central da reflexão de Guerreiro Ramos nos anos 1950. Diante do imperativo da superação do atraso, da condição periférica e subalterna, ele se dedica à crítica da produção sociológica em prol do comprometimento político dos sociólogos com seu contexto imediato, identificado à nação. Seus esforços, desde meados da década de 1940, de aproximação das ciências sociais, tais como praticadas em São Paulo, com ênfase na pesquisa empírica, e as agências governamentais, no interior das quais seria possível uma modalidade de sociologia aplicada, cedem lugar a um projeto de política científica mais incisivo, visando ao planejamento e à organização da atividade de pesquisa e da reflexão teórica em torno de uma agenda ao abrigo do Estado.

A crítica de Guerreiro se estende à prática de pesquisa levada a cabo nos centros acadêmicos paulistas, a seu ver institucionalizada de acordo com padrões estrangeiros e distante das tarefas práticas de construção da nação que a situação histórica exigia. Os estudos sobre o negro no Brasil tornam-se exemplo por excelência de uma sociologia julgada etnocêntrica e alienada, que, incapaz de reconhecer os afro-brasileiros como uma força dinâmica, uma das principais matrizes demográficas do povo brasileiro, tomava-os como exótico objeto de pesquisa, ao modo dos antropólogos estrangeiros, e contribuía para a preservação das condições culturais retardatárias nas quais se encontrava uma parcela da população negra.

A defesa de Guerreiro Ramos de uma sociologia nacional torna-se mais inteligível à luz de sua participação no segundo governo Vargas. Em 1951, ele passa a trabalhar na Casa Civil ${ }^{13}$ por indicação de Romulo de Almeida (GUERREIRO RAMOS, 1995, p. 147). No segundo semestre de 1952, começa a se reunir com um grupo de intelectuais, o chamado "Grupo de Itatiaia" (Helio Jaguaribe, Ignácio Rangel, Roland Corbisier, Miguel Reale, Hermes Lima Rocha, Israel Klabin e outros), que criou no ano seguinte o Instituto Brasileiro de Estudos Sociais e Políticos (IBESP), futuro ISEB. Diversos membros do grupo, especialmente de São Paulo, tinham sido da Ação Integralista Brasileira (AIB) (ABREU, 1975). Fazia parte da pauta de discussões do IBESP, segundo Schwartzman, "o subdesenvolvimento brasileiro, a busca de uma posição internacional de não alinhamento e de 'terceira força', um nacionalismo em relação aos recursos naturais do País, uma racionalização maior da gestão pública [e uma] maior participação de setores populares na vida política" (1981, p. 3).

\footnotetext{
${ }^{13}$ Guerreiro Ramos dirigiu uma Pesquisa de Padrão de Vida junto às classes média e operária. Essa pesquisa foi patrocinada pela Comissão Nacional de Bem-Estar Social, órgão criado pelo Estado em 1953. Oracy Nogueira ficou responsável pela pesquisa no município de Itapetininga (Sociologia, vol. 15, ํㅜ 3, p. 286).
} 
No início de sua participação no IBESP, Guerreiro Ramos escreveu O Processo da Sociologia no Brasil (1953a). O ensaio é dedicado ao sociólogo Oracy Nogueira, professor da Escola Livre de Sociologia e Política, por quem Guerreiro nutria grande simpatia em função de suas análises sobre a violência do sistema escravocrata e das críticas à concepção comumente aceita da escravidão benigna, do "bom senhor" e do "escravo passivo". Nogueira valorizou as revoltas escravas em sua pesquisa sobre as relações raciais no município de Itapetininga, que veio a integrar o "projeto Unesco" (GUERREIRO RAMOS, 1950f).

O Processo da Sociologia reflete a nova fase de sua atuação intelectual e política, no qual Guerreiro passa a disputar os rumos da institucionalização das ciências sociais no país. Em polêmica com visões de ciência em voga, como aquelas sustentadas, dentre outros, por Donald Pierson e Roger Bastide, Guerreiro problematiza nessa obra não apenas a pretensão de neutralidade axiológica por parte dos cientistas sociais, como também a universalidade do conhecimento sociológico ${ }^{14}$. Defende, em contraposição, a tese de que o condicionamento sócio-histórico da produção científica era incontornável, fato que se tornava evidente pelos imperativos de ordem prática que estavam na origem de seu desenvolvimento.

O caminho para a instituição de uma sociologia "autêntica" no país também passava pelo resgate dos autores que, na história intelectual brasileira, estiveram comprometidos com um projeto de construção nacional. Esse exercício de enraizamento de sua sociologia no passado não é gratuito e pretende, a um só tempo, legitimar seu projeto intelectual para as ciências sociais e reivindicar a existência de uma "tradição nacional", autóctone, no Brasil, à qual estaria filiado. Ela era constituída por autores como Silvio Romero, Euclides da Cunha, Alberto Torres e Oliveira Viana, cuja produção foi vista como distante dos cânones científicos, mais próxima do ensaísmo.

O pensamento destes intelectuais pautara-se por propósitos políticos e pragmáticos. Autoritários, eles se destacaram pela oposição à transplantação de instituições políticas estrangeiras, de corte liberal, na constituição do Estado-Nação. Paulino José Soares de Souza, o visconde do Uruguai, seria um dos antecessores mais remotos dessa tradição ao defender, no Império, o princípio da centralização política enquanto mais condizente com as peculiaridades da sociedade brasileira, vista como amorfa, desarticulada e marcada pelo predomínio dos interesses locais, particularistas. Nessa mesma linha, Oliveira Viana criticou o idealismo utópico das elites políticas na Primeira República, sua predileção por formulações abstratas em detrimento do estudo objetivo da realidade social do país (CARVALHO, 1991; COSER, 2008).

Coexistindo com essa vertente havia outra, que Guerreiro denomina heteronômica, alvo da ascendência de matrizes estrangeiras de pensamento e incapaz de incorporá-las criticamente. Ela representava visões teóricas desarticuladas do contexto nacional, destituída de fins programáticos e operativos. Fariam parte desse segundo grupo: Tobias Barreto, Pontes de Miranda, Tristão de Ataíde, Pinto Ferreira e Mario Lins (GUERREIRO RAMOS, 1953a, p. 10-12).

Essa linhagem desenvolve-se nos estudos raciais realizados por Nina Rodrigues, Gilberto Freyre, Arthur Ramos, Alfred Métraux, Donald Pierson e Roger Bastide, marcados por uma visão desinteressada do negro concebido como "material etnográfico", ignorando "sua presente problematicidade política e social" (idem, p. 17). Guerreiro reitera, nesse caso, críticas formuladas no final dos anos 1940, ao considerar que as ciências sociais concebiam o negro como peça museológica, acorrentado à tradição, aos estudos afro-brasileiros (idem). Ao estimular a preservação de "formas religiosas de caráter pré-letrado", aqueles estudiosos obstaculizavam o "processo de evolução cultural das massas de cor" no sentido da adoção de estilos culturais mais adequados à moderna ordem capitalista e, portanto, capazes de promover a ascensão social do negro (idem, p. 18-19).

\footnotetext{
${ }^{14} \mathrm{Na}$ introdução da obra, Guerreiro busca desacreditar a tese segundo a qual a universalidade do conhecimento estaria garantida, sociologicamente, a partir da constituição de uma comunidade científica internacional, marcada pelo intercâmbio intelectual crescente entre cientistas oriundos de diferentes partes do globo. Este argumento é utilizado explicitamente por Pierson (1945) e Bastide (1953) na defesa do caráter universal do saber sociológico, neutro e objetivo. Para Guerreiro, a consolidação de uma comunidade transnacional de cientistas sociais não implicava, no entanto, a superação do caráter perspectivista e contingente das ciências (GUERREIRO RAMOS, 1953a, p. 8).
} 
Segundo Guerreiro, no contexto de transição da sociedade brasileira, em vias de se constituir como nação autônoma nos planos econômico e cultural de sua condição colonial, as diferenças entre a corrente "consular", mimética, e a sociologia "nacional" refletiam a tensão entre a tendência à adoção irrestrita de padrões cognitivos europeus ou norte-americanos e o pensamento empenhado na fundação de uma tradição intelectual autárquica (GUERREIRO RAMOS, 1953a, p. 11).

O exercício de classificação dos intelectuais que caracteriza $O$ Processo da Sociologia no Brasil revela uma inflexão no pensamento de Guerreiro Ramos, especialmente em relação ao livro Notícias sobre as pesquisas e os estudos sociológicos no Brasil em coautoria com Evaldo da Silva Garcia (GUERREIRO RAMOS e GARCIA, 1949). O trabalho aborda um conjunto de estudos divididos entre os "impressionistas", que espelham um certo senso comum, "popular", sobre a imigração e a colonização e aqueles de natureza científica. O sociólogo registra a fragilidade da produção em ciências sociais realizada no Brasil com a exceção de São Paulo, onde a Escola Livre de Sociologia e Política e, especialmente, Donald Pierson constituíam, a seu ver, exemplos da prática sociológica moderna, calcada no trabalho coletivo de pesquisa empírica sistemática. Com O Processo, há uma guinada de Guerreiro Ramos ao revisar criticamente as noções de cientificidade sustentadas, dentre outros, pelo próprio Pierson e no abandono do critério institucional na avaliação da pertinência da produção de caráter sociológico, considerada "pré-científica" ${ }^{15}$ Favoreceu, para tal, a crítica de Guerreiro à sociologia do negro, quando passa a "contribui[r] decisivamente para restabelecer a ponte de comunicação intelectual entre o passado e o presente no pensamento social brasileiro" (SCHWARTZMAN, 1983, p. 31).

A proposta de Guerreiro de uma sociologia nacional ganha maior visibilidade no II Congresso LatinoAmericano de Sociologia, ocorrido em julho de 1953 no Rio de Janeiro e em São Paulo, no qual o autor apresenta, como presidente da Comissão de Estruturas Nacionais e Regionais, uma série de teses, recusadas em sua totalidade, sobre os afazeres sociológicos em um país em processo de desenvolvimento. Sob o efeito dos resultados do Congresso, Guerreiro Ramos torna público seus posicionamentos contra seus opositores por meio de uma série de artigos publicados no jornal Diário de Notícias, que acabam compondo, na sequência, parte do livro Cartilha Brasileira Do Aprendiz De Sociólogo (GUERREIRO RAMOS, 1954a, p. 9-12).

Na Cartilha, Guerreiro critica a adoção de soluções aos problemas sociais que são aplicadas em países desenvolvidos e que não respeitam as especificidades da sociedade brasileira. Ele considera que os investimentos na área de pesquisa necessitam estar canalizados para interpretações abrangentes dos aspectos locais e globais das estruturas nacionais. Nesse caso, o principal alvo de Guerreiro Ramos são os inúmeros "estudos de comunidade" realizados nos anos 1940 e 1950, concentrados em estudos etnográficos, descritivos, tópicos, ou seja, na visão do autor, "detalhes da vida social", com limitada capacidade de compreensão das amplas transformações da sociedade (idem, pp. 15-17). ${ }^{16}$

Dentre as teses de Guerreiro Ramos derrotadas pelo Congresso, há uma diretamente associada à questão racial:

"É francamente desaconselhável que o trabalho sociológico, direta ou indiretamente, contribua para a persistência, nas nações latino-americanas, de estilos de comportamento de caráter pré-letrado. Ao contrário, no que concerne às populações indígenas ou afroamericanas, os sociólogos devem aplicar-se no estudo e na proposição de mecanismos de

\footnotetext{
${ }^{15}$ Sobre o debate acerca dos marcos da institucionalização das ciências sociais no Brasil, ver: Lima (1999); Miceli (1989); Santos (1978); Peirano (1991[1981]); Werneck Viana (1997); Oliveira (1995); Vilhena (1997). Guerreiro Ramos, no entanto, reafirma, neste momento, a importância da ELSP e da USP na história das ciências sociais em função de o ensino e a pesquisa terem sido organizados, pelas classes dirigentes, com "objetivos práticos" (GUERREIRO RAMOS, 1953a, p. 29). Guerreiro também valoriza o papel de Fernando de Azevedo, que havia conquistado um lugar institucional para os sociólogos no âmbito universitário e cuja obra possuía "caráter pragmático, pelas suas repercussões ou através da função magisterial [sic] que parece ter sido a que se propôs" (idem, p. 30).

${ }^{16}$ Estudos recentes tem apresentado visões críticas sobre a abordagem de Guerreiro Ramos acerca dos estudos de comunidade. Ver: Lima (1999); Oliveira e Maio (2011).
} 
integração social que apressem a incorporação desses contingentes humanos na atual estrutura econômica e cultural dos países latino-americanos" (idem, p. 17).

Guerreiro retoma reflexões realizadas na segunda metade dos anos 1940, quando de sua ativa participação no TEN, influenciadas pelo antropólogo Arthur Ramos, como é o caso da visão do "comportamento de caráter pré-lógico" atribuído aos negros. Ademais, a visão integracionista de Guerreiro pressupõe que o universo étnico-racial da América Latina esteja em sintonia com o avanço do capitalismo, como condição sine qua non para superação do subdesenvolvimento. Essa tomada de posição entra em conflito com as propostas de preservação da tradição, dos "estudos etnográficos", folclóricos. A partir do Congresso de 1953, os embates ideológicos sobre o papel dos intelectuais e o padrão de trabalho sociológico a ser perseguido tornam-se questões obrigatórias. O tema das relações raciais faz parte deste processo.

\section{Movimento negro, cientistas sociais e controvérsias}

Após o II Congresso Latino-Americano de Sociologia (GUERREIRO RAMOS, 1954, p. 217), Guerreiro Ramos amplia suas críticas às ciências sociais universitárias, tendo como alvo, sobretudo, o estudo sobre as relações entre brancos e negros na cidade do Rio de Janeiro realizado por Luiz de Aguiar Costa Pinto, professor da Faculdade Nacional de Filosofia (FNFi), sob o patrocínio da Unesco. Os primeiros achados do relatório preliminar enviado pelo sociólogo em setembro de 1951 ao antropólogo Alfred Métraux ${ }^{17}$, coordenador da pesquisa da Unesco, foram publicados na revista Cultura (COSTA PINTO, 1952). Eles se transformaram em objeto de contendas na medida em que lideranças negras julgaram que Costa Pinto não reconheceu o valor da produção intelectual elaborada pelo TEN, principalmente as críticas aos estudos afrobrasileiros. Nas palavras do líder do TEN, Abdias Nascimento (1953), Costa Pinto assumira a discutível condição de "iniciador do novo ciclo de pesquisas e estudos sobre os brasileiros de cor" (idem, p. 23-24).

Na mesma linha de pensamento de Nascimento, Guerreiro Ramos opõe-se ao artigo de Costa Pinto, tratandoo como "um estudo sobre relações de raça no qual subestimando diversos trabalhos pioneiros e da maior importância toma a si próprio como o marco divisor dos estudos sobre o assunto. Como quem diz 'antes de mim e depois de mim' são dois períodos da evolução do tema". ${ }^{18} \mathrm{O}$ artigo de Costa Pinto veio a público no início do segundo semestre de 1953, ainda no contexto das repercussões das críticas sofridas por Guerreiro as suas teses apresentadas no II Congresso Latino-Americano de Sociologia.

Diante de um cenário adverso, Guerreiro publica diversos artigos no Diário de Notícias e em $O$ Jornal, no intervalo entre setembro de 1953 e janeiro de $1954^{19}$, em que radicaliza suas críticas a Costa Pinto. A abordagem do sociólogo do Departamento de Ciências Sociais da $\mathrm{FNFi}^{20}$ sobre o projeto de formação de uma elite política de cor, advinda dos setores médios negros em ascensão social, distante dos anseios e reivindicações dos setores subalternos de cor, do "negro-massa", convence, definitivamente, Guerreiro Ramos dos propósitos da sociologia acadêmica, ou seja, um enfoque sobre o negro como "material de campo", com críticas mordazes que desqualificam atores, iniciativas políticas e produção intelectual. Como afirma Abdias Nascimento, principal líder do TEN:

\footnotetext{
${ }^{17}$ Carta de Luiz de Aguiar Costa Pinto a Alfred Métraux, 1/9/1951, p. 6, in Statement on Race. REG file 323.12 A 102. Part I (Box REG 146), UNESCO Archives.

${ }^{18}$ Guerreiro Ramos afirma que o branco Costa Pinto, em sua análise das relações raciais, indicou os limites das elites dominantes ao não aceitar conviver com "um mulato que é de sua mesma geração, de sua mesma cidade, que abraçou sua mesma profissão, que atua no mesmo meio e nos mesmos campos específicos de estudo" (GUERREIRO RAMOS, 1953b, p. 2).

${ }^{19}$ Guerreiro Ramos escreve os seguintes artigos neste período: "O Negro, a UNESCO e o Carreirismo" (Diário de Notícias, 8/11/1953); "Uma Redefinição do Problema do Negro" (Diário de Notícias, 6/12/1953); "A UNESCO e o Negro Carioca" (Diário de Notícias, 20/12/1953); "Sociologia Clínica de um baiano "claro"” ( $O$ Jornal, 27/12/1953); "Interpelação à UNESCO" ( $O$ Jornal, 3/1/1954); "O Plágio" (O Jornal, 17/1/1954).

${ }^{20}$ Para uma análise da trajetória social e intelectual de Costa Pinto, ver: MAIO, 1997a; OLIVEIRA, 1995b.
} 


\begin{abstract}
“Material de campo para justificação de 'hipóteses' de trabalho? Os 'estudiosos' do negro brasileiro, transformaram-nos, em seus livros, em espetáculo, e, enquanto se divertiam à nossa custa, - ah! O pitoresco da culinária negra, o esquisito das macumbas e candomblés, a dança pitoresca e a dança exótica! - nem suspeitavam que nós, os negros, tratávamos com a vida, atuávamos sobre ela e ela sobre nós, enfim, discutíamos e lutávamos pela nossa sobrevivência" (NASCIMENTO, 1953, p. 23).
\end{abstract}

No calor das reações ao estudo de Costa Pinto, Sebastião Rodrigues Alves, amigo de Abdias Nascimento desde os anos 1930, ex-militante integralista, um dos fundadores do Comitê Democrático Afro-Brasileiro, contribuiu com diversos artigos para a coluna "Problemas e Aspirações do Negro Brasileiro", seção do Diário Trabalhista dirigida por Abdias. Ele foi articulista do jornal Quilombo (1948-1950) (GUIMARÃES e MACEDO, 2008). Alves pronunciou conferência na Associação Brasileira de Imprensa (ABI) em 1954, fazendo coro contra o pensamento de Costa Pinto, incluindo ainda o etnólogo Edison Carneiro. Em suas palavras, "é tão capcioso esse pseudocientista que tem o descalabro de afirmar estar dando um aspecto novo aos estudos do negro no Rio de Janeiro." Para isso, Costa Pinto uniu-se "a outro honorífico [Edison Carneiro] 'antropólogo e folclorista' (...). [Eles] tem [o] propósito de achincalhar o negro e permanecerem na sua costumeira posição de senhores. [S]e tornam donos do problema do negro e se lançam numa aventura perniciosa, afirmando, erroneamente, que o negro tem tais complexos, tais comportamentos e reagem dessa ou daquela forma. (...) Os 'cientistas' e 'estudiosos' tem procurado transformar nosso trabalho em arapuca ideológica." ${ }^{21}$

Os conflitos entre integralistas e comunistas no seio do movimento negro datam do período do Estado Novo. Seus desdobramentos estão presentes na conferência de Sebastião Alves sob o clima do anticomunismo e da Guerra Fria como se depreende do título da conferência: "Sociólogos Subdesenvolvidos: Infiltração Comunista no Movimento Negro no Rio de Janeiro".

A politização do estudo de Costa Pinto repercutiu também na I Reunião Brasileira de Antropologia realizada em novembro de 1953 no Museu Nacional. O etnólogo, jornalista e mulato Édison Carneiro, que participou do projeto da Unesco no Rio de Janeiro pesquisando as instituições tradicionais (religiosas e recreativas) a exemplo das escolas de samba, bem como as organizações contemporâneas dos grupos de cor (COSTA PINTO, 1952, p. 29), integrou uma mesa-redonda sobre o negro ao lado dos sociólogos Roger Bastide e José Bonifácio Rodrigues. ${ }^{22}$

Coordenador, junto com Abdias do Nascimento e Guerreiro Ramos, do $1^{\circ}$ Congresso do Negro Brasileiro, em agosto de 1950, Carneiro, que era vinculado ao Partido Comunista Brasileiro (PCB), tinha uma visão distinta dos dirigentes do Teatro Experimental do Negro (TEN). Não obstante se identificasse com as críticas a vertente afro-brasileira dos estudos sobre o negro, mantinha reservas quanto à ideologia da negritude do TEN como se observa em sua apresentação na mesa-redonda no Museu Nacional: "Com o Congresso [do Negro Brasileiro], um grupo avultado de pequeno-burgueses e burgueses intelectualizados de cor tentou dar voz a manifestações racistas, de supremacia emocional do negro, a fim de adornar o problema de acordo com a inspiração, a fórmula e a solução norte-americanas" (CARNEIRO, 1964 [1953], p. 116). Na mesma linha de Costa Pinto, Edson Carneiro questionava o projeto de valorização da raça negra contida na proposta política do TEN. ${ }^{23}$

${ }^{21}$ Alves, Sebastião Rodrigues. Conferência: "Sociólogos Subdesenvolvidos: Infiltração Comunista no Movimento Negro", 8p., s/d., in UFSCar - Biblioteca Comunitária/Fundo Florestan Fernandes, 02.04.4527.

${ }^{22}$ Diário de Notícias, 8/11/1953, p. 3.

${ }^{23}$ A tensão entre Guerreiro Ramos e Costa Pinto pode ser medida pela situação exposta pelo último: "Quando, em novembro do ano passado, teve lugar, no Rio de Janeiro, no Museu Nacional, a Primeira Reunião Brasileira de Antropologia, a qual compareceram especialistas de todo o país - um dos temas discutidos e que constava do temário amplamente divulgado, foi exatamente o dos estudos sobre relações de raça. Choveram os recados enviados por esses indivíduos [Guerreiro Ramos, Abdias do Nascimento e outros], de que lá compareceram para discutir com argumentos científicos, perante uma assembleia de cientistas, o problema em questão. Como era de esperar lá não compareceram. Os relatórios foram lidos e a discussão se fez ampla e elevada. Foi a mais 
Em dezembro de 1953, é lançado o livro de Costa Pinto, O Negro no Rio de Janeiro: relações de raça numa sociedade em mudança. Além da literatura afro-brasileira, Costa Pinto crítica a tradição de estudos raciais desenvolvidas pela Escola Sociológica de Chicago, que concebem as diferenças raciais como um processo em si ou a partir dos efeitos da dinâmica das interações interraciais, lembrando o "ciclo de relações raciais" (competição, conflito, acomodação e assimilação) formulado por Robert Park, sem levar em consideração aspectos estruturais das relações sociais, ou de forma mais ampla, as especificidades do desenvolvimento capitalista no Brasil. Na segunda parte do livro, Costa Pinto discorre sobre o cenário racial do Rio de Janeiro, mediante o estudo da demografia, da estratificação social, da ecologia, da dimensão cultural, das atitudes e estereótipos raciais. Expõe as assimetrias sociais entre brancos e negros, abordando as relações entre estrutura social, preconceito racial, movimentos sociais e, sobretudo, a liderança dos "movimentos sociais de novo tipo", na definição de Costa Pinto.

Aos olhos de Costa Pinto, Guerreiro Ramos, a principal liderança intelectual do TEN, sofria de uma série de tensões e ambiguidades próprias às pessoas de cor em processo de ascensão social. O TEN seria uma elite mergulhada em um dilema por estar nos estratos superiores da sociedade, mas não ser aceita pelas elites brancas. $\mathrm{O}$ preconceito e a discriminação com base na cor eram sintomáticos da mudança no quadro das relações raciais do país pós-escravidão, pautadas pela modernização, indicavam a resistência das classes dominantes brancas em admitir formas mais simétricas de sociabilidade, isto é, para além das relações tradicionais de subalternidade.

O recurso às práticas terapêuticas de desrecalcamento constituía uma racionalização das angústias desses segmentos, que evitariam o enfrentamento direto do racismo na expectativa de conquistar a adesão das elites brancas (COSTA PINTO, 1953, p. 276). A tentativa dessa minoria em mobilizar a massa negra estaria fadada ao insucesso em função do caráter classista de sua linguagem e aspirações. Nesse sentido, a análise de Costa Pinto sobre o mito da negritude como ideologia do racismo às avessas - falsa consciência do problema racial centrada na valorização de virtudes e qualidades supostamente intrínsecas ao negro - questiona a própria legitimidade do movimento negro, visto como "expressão ideológica de uma pequena burguesia intelectualizada e pigmentada" (idem, p. 278), incapaz de pôr em xeque o sistema de estratificação social brasileiro como um todo (idem, p. 290).

Operando com a categoria "negro-massa", expressão cunhada por Guerreiro Ramos, Costa Pinto procura enfatizar, em chave marxista, os estreitos laços entre população negra e classes subalternas - e não em torno de uma identidade cultural ou racial específica, ou ainda, em termos de sua participação em uma identidade nacional mais abrangente, anuladora das diferenças de classe. As tensões interraciais seriam expressão do acirramento da luta de classes que acompanhava o avanço do desenvolvimento capitalista no país, influindo na tomada de consciência de classe do "negro-massa". Nessa perspectiva, a superação da discriminação racial, com a integração do negro à sociedade brasileira, poderia ocorrer no bojo das transformações da ordem estrutural protagonizadas pelo proletariado. Todavia, as tensões raciais que emergem no contexto das mudanças sociais, no qual surge o negro de classe média, podem gerar uma politização que provocaria o surgimento de reivindicações de natureza racial. Um dos cenários possíveis, na perspectiva do sociólogo, é o aumento do conflito racial.

Guerreiro Ramos, por seu turno, quando de seu engajamento no TEN, preocupou-se em afirmar a necessidade de constituição de uma elite intelectual, de uma intelligentsia, baluarte do movimento negro, que não estaria vinculada a interesses e perspectivas de segmentos sociais específicos. Elevando-se acima das determinações de classe, a identidade do grupo estaria fundada, sobretudo, em afinidades intelectuais, em uma socialização cultural comum, e em um conjunto partilhado de objetivos políticos amplos: a elevação sociocultural de negros e mulatos (GUERREIRO RAMOS, 1950a, p. 49). A argumentação de Guerreiro o aproxima de Mannheim, dos intelectuais como "classe social flutuante", não identificada a interesses de classe imediatos e portadora da missão de representar a sociedade como um todo. Guerreiro negava protagonismo aos setores subalternos - que, pelo baixo grau de instrução, seriam incapazes de realizações

tranquila manhã do congresso - e cá fora a vociferação continuou em linguagem ainda mais incontinente e tom cada vez mais esganiçado (...)" (COSTA PINTO, 1954). Sobre Edison Carneiro, ver: Rossi, 2011; Vilhena, 1997. 
coletivas - e sustentava um processo de mudança conduzido "pelo alto", a ser efetivado sem provocar conflitos raciais ou de classe.

As críticas de Costa Pinto à intelectualidade do TEN reforçam em Guerreiro Ramos a crença de que os afazeres sociológicos, tais como vinham sendo institucionalizados nas universidades, estavam, em geral, descomprometidos com a realidade social, interessada, sobretudo, com o negro enquanto estudo de natureza acadêmica, cancelando o aspecto pragmático da questão. Guerreiro Ramos provoca em Costa Pinto uma reação veemente: "De uma vez por todas é preciso não confundir duas coisas bem diferentes: e que só podem ser misturadas por ignorância ou má fé: uma coisa é ideologia racial, outra coisa completamente distinta é o estudo científico de relações de raça” (COSTA PINTO, 1954, p. 2).

Costa Pinto contrapõe-se às críticas de Guerreiro, estabelecendo uma distinção entre conhecimento científico e ação política. Os dois sociólogos estão ainda embasados em visadas distintas acerca do combate ao racismo: particularismo (Guerreiro Ramos) versus universalismo (Costa Pinto), e o protagonismo da mudança atribuído a uma elite (Guerreiro Ramos) e a uma classe social, o proletariado (Costa Pinto).

\section{Roger Bastide versus Guerreiro Ramos: padrões de trabalho sociológico e antirracismo}

A análise de Guerreiro Ramos do pensamento social brasileiro, no quadro dos esforços de elaboração de uma sociologia nacional, que caminha pari passu com a crítica à sociologia alienada, foi objeto de interpelações suscitadas pelo sociólogo Roger Bastide, que era não apenas uma referência central no mundo acadêmico paulista (USP) como participava do projeto da Unesco sobre as relações raciais na cidade de São Paulo junto com Florestan Fernandes. Estudioso da cultura afro-brasileira, Bastide mantinha estreitos laços com o movimento negro (Maio, 1997a).

Bastide considera que as teses defendidas em O Processo da Sociologia no Brasil podiam ameaçar à consolidação das ciências sociais no país, encerrando-as em seu contexto local. Embora concorde com a observação de ordem geral de Guerreiro Ramos no âmbito da sociologia do conhecimento, isto é, que a ciência não se realiza em um vazio social, mas está intimamente relacionada aos seus praticantes e ao ambiente socioeconômico do qual fazem parte, o sociólogo francês se pergunta pelas condições que viabilizariam a produção sociológica de caráter universal. Enquanto Guerreiro, partindo do pressuposto do condicionamento social do conhecimento científico, avalia o mesmo a partir de um critério pragmático, de transformação da própria sociedade, Bastide se recusa a considerar que, por sofrer influência do contexto nacional, a sociologia deva ser conduzida por critérios autóctones. Em suas palavras: “e, a pretexto de que as condições nacionais ou econômicas intervêm, será preciso concluir que não devemos trabalhar senão pragmaticamente, a favor daquela nação ou daquela classe, e não objetivamente?” (BASTIDE, 1953, p. 522).

Em contraposição a Guerreiro Ramos, Bastide destaca a importância de uma sociologia elaborada com base no trabalho coletivo, na cooperação entre cientistas ("internacional dos sábios"), que, a despeito de suas diferentes origens étnicas ou nacionais, esforçam-se por pensar "universalmente", purgando-se do etnocentrismo $^{24}$. Estas seriam as condições sociais de possibilidade da sociologia, cujos praticantes, situados no domínio da ciência, no "universo dos conceitos objetivos", estariam infensos a qualquer constrangimento de natureza afetiva, política, nacional ou racial ${ }^{25}$. Como exemplo, ele lembra "a pesquisa sobre as relações raciais no Brasil [que] reuniu brasileiros, norte-americanos e franceses, numa mesma preocupação, a da verdade. Poder-se-ia dizer sem dúvida que a pesquisa foi patrocinada pela Unesco e que a Unesco tem sua filosofia. Mas não me consta que essa filosofia nos tenha embaraçado no decurso do nosso trabalho" (idem,

\footnotetext{
24 Bastide observa ainda que, assim como contatos culturais intensos em determinadas regiões do globo engendraram o desenvolvimento de grandes civilizações, os "progressos da sociologia são função [...] do contato entre sábios" (idem, p. 527).

${ }^{25}$ Segundo Bastide, a ciência deveria ser pautada pelo esforço, ainda que jamais plenamente realizável, de "desembaraçar o espírito do pesquisador de qualquer preconceito, de qualquer complexo, de qualquer colonialismo [...] ou de qualquer preconceito de cor quando se trata de pesquisa sobre os problemas raciais" (BASTIDE, 1953, p. 522).
} 
p. 522). Bastide reitera a preocupação presente no projeto enviado para Unesco no início do ano de 1951, ou seja, "o estudo deve ser projetado em bases científicas, mas tem uma origem e um fim que são igualmente extra-científicos" (BASTIDE e FERNANDES, 1951, p. 3-4). Tal como Florestan Fernandes, Roger Bastide procurou ser cauteloso na distinção entre conhecimento científico e ação política. ${ }^{26}$

$\mathrm{Na}$ perspectiva do estudo científico sobre o negro, a sociologia, por ser movida por um esforço de universalização, seria capaz de situar "os fatos brasileiros no conjunto dos fatos sociológicos", distanciandose do "pitoresco", isto é, explicando fenômenos particulares, circunscritos ao contexto brasileiro, a partir de conceitos gerais (BASTIDE, 1953, p. 525). Para Bastide, a sociologia autóctone de Guerreiro, ao encerrar o cientista em suas circunstâncias locais, torna-a particularista e reforça, ao invés de superar, o viés etnocêntrico na produção de conhecimento.

Roger Bastide não apenas critica a arbitrariedade da classificação dos intelectuais proposta por Guerreiro Ramos ("sociologia consular" $\mathrm{x}$ "sociologia integrada") como também busca identificar, entre os autores supostamente ligados à tradição de pensamento autóctone (Silvio Romero, Alberto Torres, Euclides da Cunha e Oliveira Viana), a influência de teorias raciais e geográficas europeias (idem, p. 523-524). No esforço de desestabilizar a classificação de Guerreiro, Bastide chama a atenção para a originalidade da "sociologia proustiana", "humanista", encontrada em Casa-Grande \& Senzala, de Gilberto Freyre, identificada à interpretação "consular", que estaria longe de apresentar um quadro pitoresco, ou uma visão importada, das relações sociais no Brasil (idem, p. 524). Com Freyre, "é a ciência brasileira que se apresenta como modelo a seguir aos europeus" (idem).

Do mesmo modo, a sociologia desinteressada crítica por Guerreiro não seria imune a implicações e usos políticos, nem destituída de caráter operacional, como indicavam os casos de Arthur Ramos e Gilberto Freyre. O trabalho intelectual de Arthur Ramos sobre o negro brasileiro o teria alçado à condição de diretor do Departamento de Ciências Sociais da Unesco, voltado à atenuação das tensões raciais no mundo. Não menos importante eram as implicações políticas do "mulatismo" de Gilberto Freyre que, na visão de alguns intelectuais paulistas, a exemplo de Paulo Duarte, vinha estimulando "um racismo de cor que distingue duas espécies de brasileiros, os verdadeiros, os que tem um pouco de sangue negro, e os falsos, os que tem sangue estrangeiro" (idem, p. 525). Neste ponto, Bastide critica Guerreiro por ignorar que as ideias, mesmo as aparentemente gratuitas, constituem forças em atuação no próprio mundo, transformando "o real na medida em que se enuncia[m]" (idem).

Em outro contraexemplo apresentado para rebater a tese de Guerreiro Ramos sobre a gratuidade dos estudos acadêmicos sobre o negro no país, Bastide menciona as críticas de Anísio Teixeira a Arthur Ramos, Melville Herskovits, Donald Pierson, Édison Carneiro e a ele próprio por terem lutado pela preservação dos candomblés, dificultando a incorporação dos negros à civilização ocidental. Isso porque os praticantes daquela religião se serviam das pesquisas dos cientistas sociais para reforçar sua identidade cultural. Roger Bastide recebe a crítica de Teixeira como um elogio. Afinal, o candomblé preserva a cultura dos negros e eleva a sua autoestima (BASTIDE, 1953, p. 525).

Por fim, Bastide reitera sua crença de que a fecundidade do pensamento sociológico está na razão direta da priorização de pesquisas teóricas desinteressadas. Em consonância com perspectivas como a de Donald Pierson $^{27}$, para quem a adoção, por parte do sociólogo, de imperativos práticos imediatos implicava viés, ameaça à objetividade na produção de conhecimento, Bastide afirma que a aplicação bem-sucedida da ciência dependia fundamentalmente de seu desenvolvimento teórico, de modo que ambas as atividades deviam constituir processos independentes. Uma sociologia militante, ostentando a ilusória missão de criar valores ou ideais, estaria mais próxima da filosofia social ou da política, e não da ciência. Na esteira da reflexão weberiana sobre a racionalidade científica e acerca da distância que esta devia manter em relação à

\footnotetext{
${ }^{26}$ A polêmica entre Florestan Fernandes e Guerreiro Ramos em torno do que deveria ser a prática sociológica no Brasil foi objeto de estudo de diversos autores. Ver Oliveira (1995); Werneck Vianna (1997); Villas Boas (2006); Martins (2008); Bariani (2011). Maia (2012) analisa a recepção da obra de Guerreiro Ramos no Brasil em período recente.

${ }^{27}$ Ver Maio, Oliveira e Lopes, 2013.
} 
política, Bastide observa que "o sociólogo não pode fazer outra coisa senão indicar os melhores meios para realizar fins que lhes são dados de fora" (idem, p. 526). Isto é, seu comprometimento, enquanto cientista, era sobretudo com o mundo da verdade e dos fatos, da ciência, e não com os destinos da nação ou com os fins políticos a serem perseguidos pela coletividade.

No início de 1954, Guerreiro responde a Bastide, reafirmando que "num país subdesenvolvido como o Brasil, a sociologia deve tornar-se um instrumento de autodeterminação nacional. [...] Toda sociologia autêntica origina-se e desenvolve-se em resposta a desafios existenciais. [...] O que torna a sociologia nacional não é o assunto, é a atitude dos que a fazem e a sua funcionalidade" (GUERREIRO RAMOS, 1954c, p. 2). A reflexão do sociólogo funda-se na "experiência concretamente vivida e no tratamento dos fatos de sua circunstância histórica" (idem, p. 2). No Brasil, parcela considerável da produção sociológica seria despropositada, refletindo "o estado de uma sociedade sem consciência de suas necessidades orgânicas" (idem, p. 2). Inspirando-se em Euclides da Cunha, Guerreiro avalia que obras como Psicologia do Cafuné, de Roger Bastide e Casa-Grande \& Senzala, de Gilberto Freyre, viam o Brasil "de um ponto de vista litorâneo" (idem, p. 3).

Concordando com Roger Bastide que a sociologia em qualquer país sofre a influência de "pensamentos estrangeiros", Guerreiro Ramos ressalta, contudo, a diferença, no Brasil, entre a "atitude dogmática-dedutiva em face da ciência estrangeira" e a atitude tomada por alguns intelectuais (Silvio Romero, Euclides da Cunha, Alberto Torres e Oliveira Viana) que se esforçaram "para induzir da realidade brasileira critérios de ação e pensamento". Em outras palavras, exercitaram a "capacidade crítico-assimilativa" (idem, p. 3), isto é, apropriaram-se instrumentalmente, de modo seletivo, de teorias estrangeiras tendo em vista sua maior ou menor adequação ao contexto social brasileiro.

Por último, Guerreiro Ramos indaga a atitude desinteressada do sociólogo, ao se referir ao episódio, relatado por Bastide, de que os estudos etnográficos serviriam para a preservação dos valores africanos entre os negros baianos. Para Guerreiro, o exemplo de Bastide representaria a falta de compromisso da ciência estrangeira para com os destinos dos negros no Brasil, contribuindo para a manutenção do arcaico, das "sobrevivências africanas", face ao imperativo da assimilação da população de cor. Nas palavras de Guerreiro Ramos, "num país subdesenvolvido como o Brasil, não se pode admitir, de boa fé, que se estimule a gratuidade do trabalho sociológico. Este terá que se converter ao interesse nacional de superação do atraso econômico e social do país" (idem, p. 3). Também estava em jogo, nesse caso, a concepção de ciência que ambos sustentavam. Guerreiro Ramos não admitia que a atividade científica pudesse ser um fim em si mesmo; ela era "instrumento de conquista e de assenhoramento das forças naturais e sociais" (idem, p. 3).

\section{O Problema do Negro na Sociologia Brasileira}

Em meio às controvérsias com Costa Pinto e Roger Bastide, Guerreiro Ramos estende suas críticas aos demais cientistas sociais que participaram do projeto Unesco (Florestan Fernandes, Thales de Azevedo, Charles Wagley e outros) com a publicação do artigo O Problema do Negro na Sociologia Brasileira, em fevereiro de 1954, na revista do IBESP, Cadernos de Nosso Tempo, e concluído dois meses após o lançamento do livro de Costa Pinto. Guerreiro dá continuidade a revisão do pensamento social brasileiro, iniciada em $O$ Processo da Sociologia no Brasil. Na introdução de O Problema do Negro, ele subsume a universalidade do conhecimento sociológico aos ditames da ciência nacional em países assentados em identidades culturais próprias, singulares. O compromisso do trabalho científico é com "um projeto nacional de desenvolvimento - o que transparece nos objetos em que incide. Os problemas científicos radicam-se em situações historicamente concretas, embora possam ser intrinsecamente abstratos" (GUERREIRO RAMOS, 1954a, p. 190).

Guerreiro insiste em não conceber uma prática científica desinteressada ao mesmo tempo em que considera alienada a maioria dos estudos raciais no Brasil, orientados por parâmetros das ciências sociais desenvolvidas nos contextos europeu e norte-americano. Ele investe contra a antropologia e a sociologia, marcadas pelo viés ideológico do colonialismo como no caso do uso do conceito biológico de raça, e as categorias de "estrutura social", "aculturação" e "mudança social". A seu ver, o conceito de "estrutura 
social" pressupunha uma visão estática da sociedade. Ao descrever os aspectos culturais e comportamentais de determinado grupo étnico com base na estrutura da comunidade, o antropólogo ignorava o caráter histórico e transitório dessa última, privilegiando sua atuação em favor da imutabilidade de sua sociedade (idem, p. 191).

O conceito de aculturação, por seu turno, implicava a superioridade de uma cultura sobre as demais, no sentido de que apenas um dos grupos sociais inculcava estilos de comportamento aos outros sem ser por estes afetado. A crítica se desdobra na constatação da insuficiência do conceito de mudança social, principalmente em sua utilização pela antropologia aplicada, restrita aos "aspectos puramente superestruturais" do processo de transformação social e concebendo este último por meio de medidas tópicas de "agências educacionais e sanitárias, antes que através da alteração das bases econômicas e políticas da comunidade" (idem, p. 191). Guerreiro refere-se, dentre outros estudos, às investigações socioantropológicas no setor saúde que, filiando-se a modelos norte-americanos de intervenção social, a exemplo da organização de comunidades, falhavam em reconhecer as bases macroestruturais de problemas como o elevado índice de mortalidade infantil e o predomínio, nas zonas rurais, das práticas tradicionais de cura, infensas a concepções cientificas de saúde ${ }^{28}$. As questões culturais existentes na sociedade brasileira eram "dependentes da fase de desenvolvimento econômico do Brasil". Isso significava que a abordagem prática das relações raciais no Brasil, um desafio para as ciências sociais, dependia da solução de problemas estruturais, de ordem econômica e política, o que exigia, por sua vez, uma visão teórica global sobre a sociedade brasileira (GUERREIRO RAMOS, 1954a, p. 191).

Nessa perspectiva, Guerreiro amplia o sistema de classificação dos intelectuais, inicialmente exposto n’ $O$ Processo da Sociologia. Um primeiro grupo, reunindo Silvio Romero, Euclides da Cunha, Alberto Torres e Oliveira Viana, assume uma "atitude crítico-assimilativa", isto é, seus trabalhos seriam marcados pelo esforço de reinterpretação do arcabouço teórico-metodológico europeu ou norte-americano à luz das especificidades sócio-históricas do país (idem, p. 192).

Euclides da Cunha e Alberto Torres, ainda que não destituídos de visões racialistas, teriam desconfiado da validade do conceito de raça, buscando critérios autóctones, inferidos do contexto local, para a avaliação das possibilidades de construção da unidade política do país em meio à sua diversidade étnica e cultural. Eles estavam mais interessados na formulação teórica de um padrão racial brasileiro. No plano específico do negro, esses estudos "contribuíram para arrefecer qualquer tendência para ser ele considerado do ângulo do exótico, ou como algo estranho na comunidade" (GUERREIRO RAMOS, 1954a, p. 192).

Preocupados com a consolidação de uma comunidade nacional, aqueles autores teriam abordado a situação do negro de uma perspectiva processual, considerando-o a partir da possibilidade de sua integração à nação, ainda que, em casos como o de Oliveira Viana, isso tenha significado a crença no branqueamento racial progressivo da população do país (idem, pp. 200 - 201). Em sua leitura, Guerreiro está interessado, portanto, em ressaltar a dimensão histórica do pensamento desses autores, pautado pelas ideais de evolução, de contexto histórico e, sobretudo, de mudança, a despeito do viés determinista racial que, por ventura, tenham

\footnotetext{
${ }^{28}$ A crítica de Guerreiro Ramos se dirigiu em parte à ação de sociólogos e antropólogos no setor saúde, como foi o caso dos programas de educação sanitária levados a cabo pelo Serviço Especial de Saúde Pública (SESP), em que assume destaque a participação do sociólogo José Arthur Rios. Junto a um grupo de médicos sanitaristas que buscavam articular as ações em saúde a um projeto amplo de desenvolvimento nacional, a exemplo de Mário Magalhães da Silveira, Guerreiro Ramos esteve envolvido no debate acerca da maior ou menor adequação do modelo de intervenção do SESP ao contexto brasileiro. Ver MAIO e LOPES, 2012. A análise de Guerreiro Ramos acaba não fornecendo um retrato nuançado do modelo de antropologia e sociologia aplicada, voltada para o desenvolvimento regional e a organização de comunidades que vinha se desenvolvendo no país. Cientistas sociais como José Arthur Rios, em atuação no Serviço Especial de Saúde Pública, e mesmo Donald Pierson, às voltas com as tarefas de aconselhamento técnico no âmbito do Projeto do Vale do São Francisco, mantiveram, como um dos horizontes de suas pesquisas, a possibilidade de transformação social de comunidades rurais no interior do país que não se reduzisse ao incremento técnico da produção econômica local, e de participação das ciências sociais no processo de mudança, no sentido de integração das regiões afastadas dos centros urbanos à ordem moderna. À diferença de Guerreiro, no entanto, estes cientistas sociais - nesse caso, mais próximos de uma perspectiva antropológica - conferiram destaque às mediações culturais necessárias à implementação de políticas sociais e à intervenção do poder público nas localidades (MAIO, OLIVEIRA e LOPES, 2013).
} 
apresentado em seus escritos. É o que se depreende da comparação que o sociólogo estabelece entre Euclides da Cunha, Nina Rodrigues e Arthur Ramos:

"[...] embora Euclides da Cunha tenha adotado os preconceitos da antropologia racista, soube superar as suas conotações depressivas para os brasileiros. Viu, por exemplo, o mestiço exatamente ao contrário do modo como Nina Rodrigues e Arthur Ramos viram o negro; viu os mestiços como brasileiros "retardados", como "patrícios" como "nossos irmãos" e não como elemento exótico, estranho ou mumificado. Ao contrário dos africanistas de mentalidade estática, acentuou o caráter provisório de nosso quadro de relações de raça e apontou a terapêutica para alterá-lo" (idem, p. 196).

No entender de Guerreiro Ramos, além de ter lançado uma visão ao mesmo tempo compreensiva e incorporadora sobre a população sertaneja, Euclides da Cunha teria sido o expoente de uma perspectiva sociológica autêntica sobre o país, diversa da artificialidade das interpretações "litorâneas", miméticas, caudatárias de modelos europeus.

Sem abdicar do tom polêmico, o sociólogo reivindica para si a tarefa de continuador de uma ciência social euclidiana, avessa ao "espírito consular" da sociologia acadêmica (idem, p. 197) ${ }^{29}$ Essa última ligava-se à tradição de pesquisa inaugurada pelo médico-antropólogo Nina Rodrigues, que, em chave poligenista, recusara "um lugar para o negro" na sociedade nacional, na medida em que sua suposta inferioridade biológica ameaçaria a identificação do país com os padrões civilizados, do homem branco ocidental. Aliado ao aspecto racialista, Nina Rodrigues desenvolveu estudos etnográficos sobre o negro que foram retomados nos anos 1930 pelas investigações sobre as "sobrevivências africanas" conduzidas por Arthur Ramos e pelos intelectuais envolvidos nos congressos afro-brasileiros de 1934 e 1937, como Gilberto Freyre, Édison Carneiro e Aydano do Couto Ferraz. Essa lista foi acrescida por antropólogos e Sociólogos brasileiros e estrangeiros inseridos no mundo das ciências sociais em processo de profissionalização, como Donald Pierson, Charles Wagley, Florestan Fernandes, Thales de Azevedo e Costa Pinto. Esses cientistas sociais, à exceção de Donald Pierson, que participaram do Projeto Unesco, foram alvo das críticas de Guerreiro Ramos. Eles viram o negro apenas como objeto de estudo acadêmico e, portanto, sem considerar os problemas práticos ligados à sua condição psíquica e socioeconômica (idem, p. 207).

\footnotetext{
${ }^{29}$ Sobre a reatualização do dualismo litoral - sertão nas ciências sociais praticadas no Brasil nos anos 1940 e 1950, ver Lima (1999).
} 


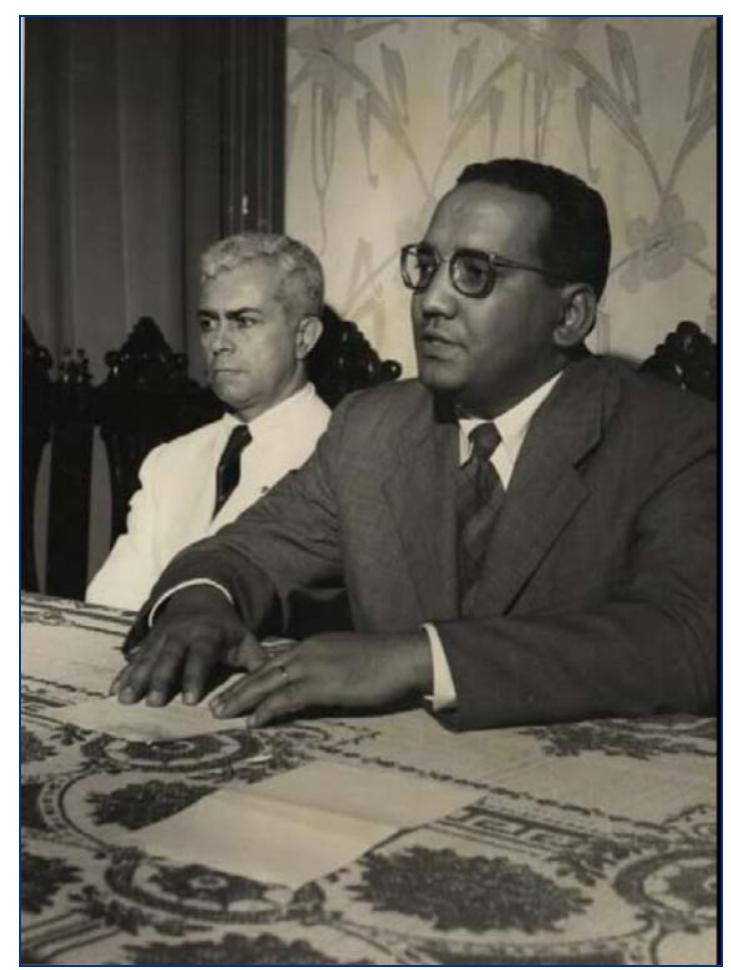

Fonte: Tese de Doutorado de Ariston Azevedo (A Sociologia Antropocêntrica de Guerreiro Ramos, 2006).

Ao lado do antropólogo Thales de Azevedo, professor da Universidade Federal da Bahia e membro da equipe de pesquisadores do "projeto Unesco de relações raciais", Guerreiro Ramos, professor da EBAP e assessor da equipe econômica do Governo Vargas, em conferência, Salvador em 8/8/1952.

Em face da alienação da "sociologia litorânea", caberia rever a própria ideia do negro como um problema na sociedade brasileira. Segundo Guerreiro, negros e mestiços professavam, em sua maioria, a religião católica, sendo os cultos afro-brasileiros frequentados, predominantemente, por negros e brancos pobres. Do mesmo modo, a presença significativa de negros entre os dados estatísticos sobre criminalidade era decorrente de condições socioeconômicas e não raciais. Além de o negro ser visto como brasileiro, na medida em que não haveria uma singularidade negra em termos de vida associativa, conjugal, profissional ou mesmo no processo de competição econômico e político, o sociólogo se pergunta sobre a perspectiva a partir da qual o negro se constituía enquanto um problema específico de investigação para os cientistas sociais no Brasil (GUERREIRO RAMOS, 1954a, p. 208).

A resposta de Guerreiro ao "problema do negro" comporta duas linhas de reflexão: a "ideologia da brancura" e a "patologia social do 'branco' brasileiro". A "ideologia da brancura" é uma crença de que "a cor da pele do negro parece constituir o obstáculo, a anormalidade a sanar. Dir-se-ia que na cultura brasileira o branco é o ideal, a norma, o valor, por excelência." (idem, p. 208). No centro dessa ideologia, estaria a estética branca assimilada pelas sociedades que sofreram a dominação colonial. Influenciado pelo etnocentrismo europeu, o brasileiro "e especialmente, o letrado, adere psicologicamente a um padrão estético europeu e vê os acidentes étnicos do país e a si próprio, do ponto de vista deste. Isto é verdade, tanto com referência ao brasileiro de cor como ao claro." (idem, p. 211). Portanto, os estudos sociológicos e antropológicos sobre o negro, inclusive os realizados pela Unesco, não passariam de achados de uma "sociologia consular", de um país visto de fora. Exemplo dessa experiência se encontra no uso dos conceitos utilizados pela Escola Sociológica de Chicago (aculturação, homem marginal, estrutura, função, raça-classe, área) (idem, p. 212), compartilhados por Guerreiro Ramos até o final dos anos 1940.

Em contraposição à "sociologia consular", Guerreiro julga que a solução para o "problema do negro" exige que se parta a um só tempo de sua condição autêntica e de sua própria experiência, vivência efetiva, traduzida pela expressão niger sum, ou seja: "sou negro, identifico como meu o corpo em que o meu eu está 
inserido, atribuo a sua cor à suscetibilidade de ser valorizada esteticamente e considero a minha condição étnica como um dos suportes do meu orgulho pessoal - eis aí toda uma propedêutica sociológica, todo um ponto de partida para a elaboração de uma hermenêutica da situação do negro no Brasil” (idem, p. 213).

A assunção à condição de negro permitiria análise acurada dos limites da visão sobre a população de cor como aculturada, definição própria ao etnocentrismo do branco brasileiro. Nesse sentido, o "problema do negro" passa, na verdade, a ser visto por Guerreiro como "patologia social do branco". Esta "patologia" grassaria especialmente no Nordeste, pontuada pela enorme dificuldade da classe dominante, inclusive dos intelectuais, de reconhecer e valorizar a miscigenação brasileira. Em outras palavras, segundo Guerreiro, "o nosso branco é, do ponto de vista antropológico, um mestiço, sendo, entre nós, pequena minoria o branco não portador de sangue negro" (GUERREIRO RAMOS, 1957, p. 180, grifo do autor).

Diante de uma nação em intenso processo de urbanização e industrialização, que se traduziria pela mobilidade social vertical, contemplando negros e brancos, a "patologia social do 'branco' brasileiro" seria sinônimo de antinação, indicando um "sintoma de escassa integração social de seus elementos..." (idem, p. 191). Enfim, a "patologia social do branco brasileiro" sofreria de dissintonia face à constituição de uma sociedade autêntica, infensa às investidas da transplantação cultural norte-americana e europeia.

Assim, o "problema do negro" era, sobretudo, um problema dos estigmas incorporados pelo branco e pelo negro, na medida em que apresentavam uma mentalidade colonizada, alienada da realidade étnica característica do Brasil. Por encarar o negro como elemento exótico, sendo incapaz de reconhecer o fato de que este constitui o perfil da própria população brasileira, a abordagem socioantropológica acadêmica seria alienada, operando com esquemas cognitivos europeus e tendo como referência o indivíduo branco, e não o brasileiro.

Frente a esse quadro adverso, Guerreiro Ramos desenvolve uma reflexão sobre a negritude, ao considerar que só uma sociologia do negro operacionalizada por uma elite negra poderia atingir uma solução satisfatória no terreno das desigualdades raciais. Para isso, o pesquisador deveria "partir de uma situação vital [...] aberto à realidade fática e, também, aberto interiormente para a originalidade" (GUERREIRO RAMOS, 1954, p. 213).

Dessa maneira, haveria o negro como objeto de estudo dos profissionais da sociologia institucionalizada e o negro como uma vivência, como uma subjetividade, enfim, como uma condição existencial. Essa corrente estaria mais interessada em "transformar a condição humana do negro na sociedade brasileira do que descrever ou interpretar os aspectos pitorescos e particularíssimos da situação da gente de cor" (idem, p. 193, ênfases do autor). O Teatro Experimental do Negro representaria esta nova fase político-intelectual dos estudos sobre o negro. Ao elucidar as origens do TEN, Guerreiro apresenta o roteiro de uma possível história do movimento negro desde a colônia, por meio das diversas associações, insurreições, resistências e lutas de libertação da população de cor. Nessa corrente, são destacados intelectuais como Joaquim Nabuco e Álvaro Bomilcar. O TEN representa a fase transformadora, engajada, contemporânea, da luta dos negros que combinaria as técnicas desrecalcamento das condições psicossociais do negro com a formulação e implementação de políticas públicas de combate ao racismo. 


\section{Considerações finais}

Na primeira parte deste artigo, procurei entrelaçar a formação social e intelectual de Guerreiro Ramos com as marcas do preconceito de cor. A condição de mulato foi uma variável importante na trajetória do sociólogo, ou seja, "um homem pegado de mau jeito pela sorte", nas palavras de Guerreiro, quando de seu ingresso no TEN, seria uma barreira a sua ascensão social. Em seguida, tratei da sua participação política no Teatro Experimental do Negro em meio ao debate sobre os padrões de cientificidade da sociologia e os desafios da intervenção social a que o sociólogo era instado a desempenhar no domínio do enfrentamento do racismo.

Com efeito, as críticas de Guerreiro Ramos aos estudos realizados pela Unesco assumem um papel importante em suas reflexões sobre a função dos intelectuais, a construção de uma sociologia nacional e o lugar das relações raciais, do racismo e das formas de combatê-lo. Desde o final dos anos 1940, Guerreiro julgava que os estudos sobre o negro deveriam estar destituídos de uma perspectiva acadêmica, procurando estar investidos de sentido prático. Com o ciclo de pesquisas da Unesco, Guerreiro Ramos se tornará um duro crítico da sociologia acadêmica.

As contendas entre Guerreiro Ramos, Costa Pinto e Roger Bastide apontam para concepções distintas de participação política dos cientistas sociais. No plano mais específico do confronto entre Guerreiro e Costa Pinto, em que estiveram em jogo visões diversas sobre os afazeres sociológicos, a dinâmica da mudança social e do enfrentamento do racismo, vale destacar a narrativa sarcástica de Costa Pinto sobre o TEN em $O$ Negro no Rio de Janeiro. Ela espelha conflitos ideológicos e políticos que estão associados à militância integralista de Guerreiro e a atuação comunista de Costa Pinto nos anos 1930. Eles se desdobrarão durante o Estado Novo, na luta da UNE contra o fascismo e continuarão nas discussões ocorridas no $1^{\circ}$ Congresso do Negro Brasileiro em 1950, onde se destacaram Guerreiro Ramos, Abdias Nascimento, Ironildes Rodrigues entre outros, pelo TEN, e intelectuais próximos ao PCB (Darcy Ribeiro, Edison Carneiro e Costa Pinto). ${ }^{30}$

Entre as disputas políticas encontra-se a questão da agência, da legitimidade do ator político, do movimento negro, da adoção de medidas julgadas particularistas, racialistas, em lugar de soluções universalistas no combate ao racismo. $\mathrm{O}$ estudo de Costa Pinto deixa evidente as tensões que permeiam a análise do autor, por vezes irônica, dos movimentos de novo tipo, como ele os denomina. Como efeito, houve uma politização dos resultados da pesquisa em razão da reação de representantes do movimento negro.

Quanto ao tema do desenvolvimento, Costa Pinto não tem a visão otimista de Guerreiro. Não credita à industrialização, que gera as mudanças sociais, a capacidade de superação do racismo. Ele concebe, na verdade, a possibilidade de aguçamento dos conflitos. Guerreiro Ramos, por sua vez, considera que o desenvolvimento nacional teria um sentido incorporador, sem tensões raciais.

Para além dos distintos padrões de trabalho científico, as controvérsias entre Guerreiro Ramos e Roger Bastide também contemplam a análise da função social de determinados cientistas sociais, que são vistos por Guerreiro como pertencentes à sociologia "consular", estática, não importando os aspectos dinâmicos, sociológicos da vida dos negros. Em contraposição a Guerreiro, Bastide oferece os exemplos de Gilberto Freyre e Arthur Ramos. No primeiro caso, Gilberto Freyre foi alvo de intensas críticas racistas de intelectuais paulistas (Paulo Duarte, Raul Milliet e Vivaldo Coaracy), adeptos da ideologia do branqueamento, por sua defesa da valorização da população de cor, da visão de um país mestiço. Desse modo, as controvérsias giravam em torno de visões de nação, da afirmação de uma identidade nacional e da dimensão incomoda que representava um projeto político e cultural que contemplasse a miscigenação de grupos étnico-raciais. Nessa

\footnotetext{
${ }^{30}$ Costa Pinto colaborou na redação do livro Quinta Coluna e Integralismo (Rio de Janeiro, Departamento Editorial da União Nacional dos Estudantes, 1943[1942]), no qual consta o nome de Guerreiro Ramos, que integrava um grupo de integralistas da Bahia. No mesmo período, em carta a Donald Pierson, Costa Pinto declara: "infelizmente as notícias que agora posso lhe dar do Guerreiro Ramos não são muitas. Há muito que não o vejo nem sei o que se passa com ele. Confesso-lhe que minhas relações com este moço não são das melhores, por longas razões, e por isto não sei de seu paradeiro. Posso, entretanto, informar-me de seu endereço atual ou então transmitir-lhe algum recado seu." (ago./set. de 1943), Fundo Donald Pierson, AEL/Unicamp, 1p. Entre as "longas razões", deveria constar os conflitos ideológicos e políticos entre Costa Pinto e Guerreiro Ramos.
} 
ocasião, em maio de 1947, Freyre contou com o apoio de escritores (José Lins do Rego, Rachel de Queiroz) e representantes do movimento negro (José Correia Leite, Justiniano Costa, Francisco Napoleão). A polêmica suscitou poucos anos depois a realização do "projeto Unesco de relações raciais" em São Paulo (Maio, 1997a).

A relevância atribuída por Bastide a Gilberto Freyre no debate sobre o racismo no pós-2 ${ }^{\mathrm{a}}$ Guerra Mundial é extensiva ao antropólogo Arthur Ramos, que foi alvo de contundentes críticas de Guerreiro Ramos por ser considerado um representante dos estudos afro-brasileiros, do passado, do atraso, sem qualquer compromisso com as mudanças sociais. Contudo, a luta contra o racismo foi tema constante na obra e no engajamento político de Ramos nos anos 1930 e 1940, culminando com a sua indicação para a direção do Departamento de Ciências Sociais da Unesco. Nesse momento, a antropologia de Arthur Ramos já sinalizava, tanto por meio de estudos etnográficos quanto por investigações sociológicas acerca das desigualdades entre brancos e negros. Na versão preliminar do "projeto Unesco de relações raciais" de 1949, Ramos chegou a inserir no plano o tema das "tensões raciais" como um dos eixos privilegiados de análise da sociedade brasileira. Deixou formulado, em linhas gerais, uma proposta de desenvolvimento das ciências sociais na periferia nos primórdios da Unesco (Maio, 1999b).

As visões distintas de Guerreiro Ramos, Costa Pinto e Roger Bastide trazem à tona o tema do papel dos intelectuais na vida pública, questão obrigatória na década de 1950. Nesse sentido, os estudos de Guerreiro sobre o negro na virada dos anos 1940 para 1950 registram o afã da sociologia de seu tempo por novos padrões de cientificidade, indicando também o papel de intervenção social que o cientista social era instado a desempenhar no domínio do enfrentamento do racismo. A conviç̧ão do sociólogo em uma ciência engajada foi reforçada diante das discussões acerca das desigualdades raciais, das práticas psicossociais de elevação da autoestima, dos esforços em reunir intelectuais brancos e negros numa frente antirracista e as contendas travadas no campo intelectual. Para isso, "uma sociologia do negro em mangas de camisa", movida pelo pragmatismo, deveria ter por base a vivência das dificuldades, o engajamento que permitiria um certeiro fazer sociológico. A partir do ativismo de Guerreiro Ramos no TEN e, sobretudo, o desenvolvimento do seu pensamento nos anos 1950 indicam que a questão racial foi um tema-chave acionado tanto para a composição do retrato de uma nação subdesenvolvida, quanto para a formulação de um projeto nacional capaz de modernizá-la.

\section{Referências}

ABREU, A. A. de. Nationalisme et action politique au Brésil: Une étude sur l'ISEB. Thése Pour le Doctorat de $3^{\circ}$ Cycle. Paris: Université René-Descartes, 1975.

AZEVÊDO, A. A Sociologia antropocêntrica de Alberto Guerreiro Ramos. Tese de Doutorado. Universidade Federal de Santa Catarina, 2006.

AZEVEDO, T. Ascensão Social das Pessoas de Cor. Salvador, 1951. 63 p. mimeo.

BARBOSA, M. Guerreiro Ramos e o personalismo negro. Dissertação de Mestrado. FFLCH/USP, 2004.

BARIANI, E. Guerreiro Ramos e a rendenção sociológica: capitalismo e sociologia no Brasil. São Paulo: Editora Unesp, 2011.

BASTIDE, R. O Preconceito Racial em São Paulo (Projeto de Estudo). São Paulo, Publicação do Instituto de Administração da Universidade de São Paulo, n. 115, abril de 1951. 1-49 p.

BASTIDE, R. Carta Aberta A Guerreiro Ramos. Anhembi, v. 12, n. 36, p. 521-528, 1953.

CARNEIRO, E. Os estudos brasileiros do negro. In: Ladinos e Crioulos. Rio de Janeiro, Editora Civilização Brasileira, 1964[1953]. 103-118 p. 
CARvalHO, J. M. de. A utopia de Oliveira Viana. Estudos Históricos, Rio de Janeiro, v. 4, n. 7, p. 82 - $99,1991$.

COSER, I. Visconde de Uruguai: centralização e federalismo no Brasil (1823 - 1866). Belo Horizonte: Ed. UFMG; IUPERJ/UCAM, 2008.

COSTA, H. Fala, Crioulo. Rio de Janeiro, Editora Record, 1982.

COSTA PINTO, L. de A. Introdução ao Estudo do Negro no Rio de Janeiro (Nota Prévia). Cultura, v. 3, n. 5, p. 85$102,1952$.

COSTA PINTO, L. de A. O Negro no Rio de Janeiro: Relações de Raças numa sociedade em mudança. São Paulo: Companhia Editora Nacional, 1953.

COSTA PINTO, L. de A. Ciência Social e Ideologia Racial (esclarecendo intencionais obscuridades). O Jornal, 10 de Janeiro de 1954. 2 p.

GUERREIRO RAMOS, A. Sentido da poesia contemporânea. Cadernos da Hora Presente, p. 86-103, 1939.

GUERREIRO RAMOS, A. Literatura latino-americana. Cultura Política, v. 1, n. 6, p. 285-288, 1941.

GUERREIRo RAMOS, A. Aspectos Sociológicos da Puericultura. Coleção D.N.C., n. 109, Imprensa Nacional, Rio de Janeiro. 1944.

GUERREIRO RAMOS, A. Apresentação da Grupoterapia. Quilombo, v. 1, n. 3, Junho 1949.

GUERREIRO RAMOS, A. O Negro no Brasil e um exame de consciência. In: NASCIMENTO, A. et al. Relações de Raça no Brasil. Rio de Janeiro: Edições Quilombo, 1950. 33-46 p.

GUERREIRO RAMOS, A. O Teatro Experimental do Negro e seu instituto de pesquisa sociológica. In: NASCIMENTO, A. et al. Relações de Raça no Brasil. Rio de Janeiro: Edições Quilombo, 1950a.

GUERREIRO RAMOS, A. Narcisismo branco do negro brasileiro. A Manhã, 12 de novembro, 1950 b. 1 e 3 p.

GUERREIRO RAMOS, A. Teoria e Prática do Psicodrama. Quilombo, v. 2, n. 6, p. 6-7, 1950c.

GUERREIRO RAMOS, A. Teoria e prática do sociodrama. In: NASCIMENTO, A. et al. Relações de Raça no Brasil. Rio de Janeiro: Edições Quilombo, v. 2, n. 7/8, p. 9, 1950d.

GUERREIRO RAMOS, A. O Museu como sucedâneo da violência. In: NASCIMENTO, A. et al. Relações de Raça no Brasil. Rio de Janeiro: Edições Quilombo. 1950e. 47-50 p.

GUERREIRO RAMOS, A. Senhores e Escravos no Brasil. A Manhã. Rio de Janeiro, 22 de Outubro de 1950f. 2-3 p.

GUERREIRO RAMOS, A. A Unesco e as relações de raça. In: NASCIMENTO, A. O negro revoltado. Rio de Janeiro: Nova Fronteira, 1982 [1950].

GUERREIRO RAMOS, A. O Processo da Sociologia no Brasil - esquema de uma história das ideias. Rio de Janeiro: Edições Quilombo, 1953a.

GUERREIRO RAMOS, A. A UNESCO e o negro carioca. Diário de Notícias, Seção Letras e Artes. 20 de Dezembro de 1953b. 2 p.

GUERREIRO RAMOS, A. O Negro, a Unesco e o carreirismo. Diário de Notícias, Seção Letras e Artes, 8 de Dezembro de 1953c.

GUERREIRO RAMOS, A. Uma Redefinição do Problema do Negro. Diário de Notícias, 6 de Dezembro de 1953 d.

GUERREIRO RAMOS, A. A UNESCO e o Negro Carioca. Diário de Notícias, 20 de Dezembro de 1953e. 
GUERREIRO RAMOS, A. Sociologia Clínica de um baiano ‘claro’. O Jornal, 27 de Dezembro de $1953 \mathrm{f}$.

GUERREIRO RAMOS, A. Interpelação à UNESCO. O Jornal, 03 de Janeiro de 1954a.

GUERREIRO RAMOS, A. O Plágio. O Jornal, 17 de Janeiro de 1954b.

GUERREIRO RAMOS, A. O Problema do Negro na Sociologia Brasileira. Cadernos do Nosso Tempo, n. 2, p. 189230, Jan./Jul. 1954c.

GUERREIRO RAMOS, A. Interperlação à UNESCO. I: O Jornal, 3 de Janeiro de 1954d. 2-3 p.

GUERREIRO RAMOS, A. Resposta A Roger Bastide. Diário de Notícias, 10 de Janeiro de 1954e. 2-3 p.

GUERREIRO RAMOS, A. Sobre a crise brasileira e a sociologia no Brasil, In: Guerreiro RAMOS, A. Introdução Crítica à Sociologia Brasileira. Rio de Janeiro, Editora Andes, 1957. 205-216 p.

GUERREIRO RAMOS, A. Entrevista com Guerreiro Ramos. In: OLIVEIRA, L. L. A Sociologia do Guerreiro. Rio de Janeiro: Editora UFRJ, 1995.

GUERREIRO RAMOS, A.; GARCIA, E. Notícias sobre as pesquisas e os estudos sociológicos no Brasil (19401949). Rio de Janeiro: Conselho de Imigração e Colonização, 1949.

GUIMARÃES, A. S.; MACEDO, M. Diário Trabalhista e Democracia Racial Negra dos Anos 1940. Dados, v. 51, n. 1, p. $143-182,2008$.

INSTITUTO NACIONAL DO NEGRO. Quilombo, v. 1, n. 3, p. 11, Junho 1949.

LESSER, J. Welcoming The Undesirables: Brazil and The Jewish Question. Berkeley: University of California Press, 1995.

LIMA, N. T. Um Sertão Chamado Brasil: Intelectuais e representação geográfica da identidade nacional. Rio de Janeiro: Revan, IUPERJ, UCAM, 1999.

LOPES, T. da C. Sociologia e Puericultura no Pensamento de Guerreiro Ramos: Diálogos com a Escola de Chicago (1943-1948). Dissertação de Mestrado em História das Ciências e da Saúde. Rio de Janeiro, Fundação Oswaldo Cruz/Casa de Oswaldo Cruz, 2012.

MAIA, J. M. Reputações à brasileira: o caso de Guerreiro Ramos. Sociologia \& Antropologia. Rio de Janeiro, v. 2 , n. 4, p. 265-294, nov. 2012.

MAIO, M. C. Uma Polêmica Esquecida: Costa Pinto, Guerreiro Ramos e o tema das Relações Raciais. Dados, v. 40, n. 1, p. 127-163, 1997a.

MAIO, M. C. A história do projeto UNESCO: estudos raciais e Ciências Sociais no Brasil. Rio de Janeiro, 346p. Tese (Doutorado). Instituto Universitário de Pesquisas do Rio de Janeiro, 1997b.

MAIO, M. C. Tempo controverso: Gilberto Freyre e o Projeto UNESCO, Tempo Social, v. 11, n. 1, p. 111-136, 1999a.

MAIO, M. C. O projeto Unesco e a agenda das ciências sociais no Brasil dos anos 1940 e 50 . Revista Brasileira de Ciências Sociais, v. 14, n. 41, p. 141-158, 1999 b.

MAIO, M. C.; LOPES, T. da C. Da Escola de Chicago ao nacional-desenvolvimentismo: saúde e nação no pensamento de Alberto Guerreiro Ramos (1940 - 1950). Sociologias, v. 14, n. 30, p. 290-329, Mai./Ago. 2012.

MAIO, M. C.; OLIVEIRA, N. da S.; LOPES, T. da C. Donald Pierson e o Projeto do Vale do Rio São Francisco: cientistas sociais em ação na era do desenvolvimento. Dados, Rio de Janeiro, v. 56, n. 2, p. 245-284, 2013.

MAIO, M. C. Guerreiro Ramos interpela a Unesco: ciências sociais, militância e antirracismo. Cadernos CRH [online], v. 28, n. 73, p. 77-90, 2015. 
MARTINS, T. G. Florestan Fernandes e Guerreiro Ramos: para além de um debate. Tese (doutorado). Universidade Estadual de Campinas, Instituto de Filosofia e Ciências Humanas. São Paulo, 2008.

MICELI, S. Condicionantes do Desenvolvimento das Ciências Sociais. In: MICELI, S. (Org.). História das Ciências Sociais no Brasil, v. 1. São Paulo: Idesp/Vértice/Finep, 1989.

NASCIMENTO, A. Espírito e Fisionomia do Teatro Experimental do Negro. Quilombo, v. 1, n. 3, p. 11, Junho 1949.

NASCIMENTO, A. Cartaz: Guerreiro Ramos. Quilombo, v. 2, n. 9, p. 2, 1950.

NASCIMENTO, A. Nós, Os Negros, e a UNESCO. Panfleto, v. 5, n. 5, p. 23-24, 1953.

NASCIMENTO, A. O Negro Revoltado. Rio de Janeiro: Editora Nova Fronteira, 2. ed., 1982.

OLIVEIRA, L. L. A Sociologia do Guerreiro. Rio de Janeiro: Editora UFRJ, 1995a.

OLIVEIRA, L. L. As Ciências no Rio de Janeiro. In: MICELI, S. (Org.). História das Ciências Sociais no Brasil. v. 2. São Paulo: Idesp/ Sumaré/ Fapesp, 1995b.

OLIVEIRA, N. da S.; MAIO, M. C. Estudos de Comunidade e ciências sociais no Brasil, Sociedade \& Estado, v. 26, n. 3, p. 521-550, 2011.

PEIRANO, M. G. e S. The Anthropology of anthropology: the Brazilian Case. Série Antropologia, n. 110. Brasília: Fundação Universidade de Brasília, 1991.

PIERSON, D. Teoria e Pesquisa em Sociologia. São Paulo: Companhia Editora Nacional, 1945.

ROSSI, L. G. F. O Intelectual "Feiticeiro": Édison Carneiro e o campo das relações raciais no Brasil. Tese de Doutorado em Antropologia Social, IFCH/UNICAMP, 2011.

SANTOS, W. G. dos. Ordem Burguesa e Liberalismo Político no Brasil. São Paulo: Duas Cidades, 1978.

SCHWARTZMAN, S. O Pensamento Nacionalista e os Cadernos do Nosso Tempo. Brasília, Editora da UnB, 1981.

SCHWARTZMAN, S. Contribuição de Guerreiro Ramos para a Sociologia Brasileira - Primeiro Painel. Rev. Adm. Pública, v. 17, n. 2, p. 30-32, 1983.

SOARES, L. A. Alves. Guerreiro Ramos: a trajetória de um pensamento. Rev. Adm. Pública, v. 29, n. 2, p. 33-50, 1995.

STONEQUIST, E. V. The Marginal Man: A Study in Personality and Culture Conflict. New York: Charles Scribner's Sons, 1937.

VILHENA, L. R. da P. Projeto e Missão: o movimento folclórico brasileiro (1947-1964). Rio de Janeiro: Editora FGV, 1997.

VILLAS BÔAS, G. Mudança provocada: passado e futuro no pensamento sociológico brasileiro. Rio de Janeiro: Editora FGV, 2006.

WERNECK VIANNA, L. A Revolução passiva: iberismo e americanismo no Brasil. Rio de Janeiro: Revan, 1997. 